\title{
The screening and scoping of Environmental Impact Assessment and Strategic Environmental Assessment of Carbon Capture and Storage in the Netherlands
}

\author{
Joris Koornneef* ${ }^{*}$, André Faaij, Wim Turkenburg \\ a Department of Science, Technology and Society, Copernicus Institute for Sustainable Development and Innovation, \\ Utrecht University, The Netherlands
}

Received 31 May 2007; received in revised form 31 July 2007; accepted 9 August 2007

Available online 26 December 2007

\begin{abstract}
The Environmental Impact Assessment (EIA) and Strategic Environmental Assessment (SEA) are procedural tools which have as goal to assess and evaluate possible environmental effects of, respectively, a proposed project or policy plan. The goal of this article is to explore possible bottlenecks in applying both the EIA and SEA procedures on Carbon Capture and Storage (CCS) activities in the Netherlands, as experience is currently minimal or lacking. In this study we focus mainly on the institutional and procedural aspects of the screening and scoping phases of both procedures. This is achieved by reviewing EIA and SEA procedures for analogue projects for the three distinctive process steps of a CCS project, namely the power plant with capture, the transport and finally the underground storage of the $\mathrm{CO}_{2}$. Additionally, EIA and SEA or similar procedures on CCS in other countries are reviewed and the legal framework for the Dutch EIA and SEA is studied. This article shows a concise overview of the EIA and SEA procedure in the Netherlands and the relation between both procedures. Based on our findings we have constructed a conceptual taxonomy for the scope of both procedures for CCS in the Netherlands. This taxonomy conceptualizes the possible integration of assessing the environmental impacts for tiered levels of decision making. This integration might be needed for first CCS projects as decisions on the strategic (spatial planning) level are currently absent for CCS in the Netherlands. Perpendicular to such integration is the integration of linked activities in the CCS chain and their alternatives, into one procedure. We argue that it would be beneficial to combine the separate EIA procedures for CCS activities into one procedure or at least provide close linkage between them. This issue should be carefully considered by regulators, competent authorities and project initiators in an early
\end{abstract}

\footnotetext{
Abbreviations: AoG, Advises on the Guidelines (by the NCEIA); CCS, Carbon Capture and Storage; $\mathrm{CO}_{2}$, Carbon dioxide; ECBM, Enhanced Coal Bed Methane; EGR, Enhanced Gas Recovery; EIA, Environmental Impact Assessment; EIS, Environmental Impact Statement; EOR, Enhanced Oil Recovery; EU, European Union; IGCC, Integrated Gasification Combined Cycle; kt, kilo tonne (metric); LNG, Liquefied Natural Gas; NAM, Dutch Oil Company (Nederlandse Aardolie Maatschappij); NGCC, Natural Gas Combined Cycle; NCEIA, Netherlands Commission for the Environmental Impact Assessment (Commissie MER); NWMP, National Waste Management Plan; Mt, Mega tonne (metric); SBUI, National Structure Plan for Pipelines; SEA, Strategic Environmental Assessment; SEV, National Structure Plan for the Electricity Supply; UGS, underground gas storage.

* Corresponding author. Willem C. Van Unnikgebouw, room 925, Heidelberglaan 2, 3584 CS, Utrecht, The Netherlands. Tel.: +31 30 253 $3544 /$ 7600; fax: +31302537601 .

E-mail addresses: j.m.koornneef@uu.nl (J. Koornneef), a.faaij@uu.nl (A. Faaij), w.c.turkenburg@uu.nl (W. Turkenburg).
} 
stage to avoid delaying legal procedures in the future. For the same reason also early involvement of public, interested parties and the Netherlands Commission for the Environmental Impact Assessment in the scoping phase of the procedures is desired.

(C) 2007 Elsevier Inc. All rights reserved.

Keywords: Carbon Capture and Storage; Spatial policy; Strategic Environmental Impact Assessment; Regulation; Implementation

\section{Introduction}

It is widely accepted that the emission of $\mathrm{CO}_{2}$ which is formed with the combustion of fossil fuels, contributes to the greenhouse effect and consequently to global warming. In the Dutch 4th National Environmental Policy Plan the capture of $\mathrm{CO}_{2}$ and its storage in the underground (CCS) is considered to be a third option (additional to energy conservation and renewable energy technologies) that may be applied to reduce anthropogenic $\mathrm{CO}_{2}$ emissions into the atmosphere substantially (VROM, 2001). In the most recent coalition agreement between the parliamentary groups of the Lower House targets were formulated to reduce Greenhouse Gas (GHG) emissions by $30 \%$ in 2020 compared to the level in 1990. This may provide a strong incentive to employ Carbon Capture and Storage in the Netherlands (CDA et al., 2007).

The EIA procedure is a procedural tool, which has as goal to assess and evaluate possible environmental effects of a proposed project and its reasonable alternatives, which can have significant effects on the natural and man-made environment (Wood, 2003). A related procedure is the Strategic Environmental Assessment (SEA), which has as goal to include environmental impacts into strategic decision making by administrative bodies. More specifically, it applies on strategic decisions in governmental policies, plans and programs.

Given that plans are currently being drafted for CCS (pilot) projects, there is a growing need for clarity on administrative, juridical and environmental implications of these projects (see also (Mace et al., 2007)). Furthermore, possibilities for participation of the public in both the SEA and EIA procedure may play an important role in the public acceptance of CCS plans and projects. This emphasizes that understanding is needed on how to apply both the EIA and SEA procedure in the case of CCS.

International experience with the application of both procedural tools on CCS activities exists and is growing with the planning and implementation of CCS (demonstration) projects worldwide. In the Netherlands experience is minimal though growing with the initiation of several EIA's for power plants, which in the future may be equipped with $\mathrm{CO}_{2}$ capture installations (Commissie MER, 2006c, 2006d, 2006e). Another initiative, taken by the Dutch Oil Company (NAM) and supported by four provinces ${ }^{1}$, is also adding to the knowledge base: the $\mathrm{AMESCO}^{2}$ project. It has the goal to produce a paper which can be used as a reference guide for future EIA's for underground $\mathrm{CO}_{2}$ storage activities. This 'generic' EIA is being drafted to "prevent identical environmental studies being performed for each location" (Provincie Drenthe, 2006). Also, there is substantial experience gained with EIA procedures on projects which can be considered as analogues to $\mathrm{CO}_{2}$ capture, transport and storage.

The goal of this article is to explore possible bottlenecks in applying both the EIA and SEA procedure on CCS activities in the Netherlands and suggest future actions to resolve these. Finnveden et al. (2003) distinguishes three elements of an SEA: institutional arrangements, the procedure and applied methods. To scope this study we follow this differentiation. A detailed overview of environmental impacts due to the application of $\mathrm{CO}_{2}$ capture, transport and storage in electricity generation is not within the scope of this article and will be the subject of future work. In this article we will focus mainly on the institutional and procedural aspects of both the EIA and SEA procedure applied on CCS projects. The procedures comprise several phases or steps to be concluded. In this article we will focus on the screening and scoping phase. Following the goal and demarcation of the study the following main research question is formulated:

What are the possible concerns for project initiators and administrative bodies regarding the institutional arrangements and procedural elements in the screening and scoping phase of both the EIA and SEA procedure when applied on CCS activities?

Specific questions to be answered are:

o Under what circumstances is in the Netherlands an EIA required for the realization of CCS activities?

\footnotetext{
${ }^{1}$ The Netherlands is administratively divided into 12 provinces. The provincial government is responsible for the formulation of policy on a regional level.

${ }^{2}$ Generic Environmental Impact Study $\mathrm{CO}_{2}$ storage (in Dutch).
} 
o Under what circumstances is in the Netherlands an SEA required for the formulation of governmental plans which include CCS activities?

o What are the reasonable alternatives for projects and plans to be assessed on various levels of decision making in both the EIA and SEA procedures for CCS activities?

\section{Methodology}

The research questions are answered mainly through the review of literature on CCS technology and analogue projects. Analogue projects are reviewed for the three distinctive elements of a CCS project, namely the power plant with capture, the transport and finally the underground storage of $\mathrm{CO}_{2}$. The selected analogues include the construction of new power plants, transport of natural gas by pipelines, underground natural gas storage (UGS), gas production and enhanced oil recovery projects. Also, EIA and SEA (type) assessments for CCS in other countries are reviewed. An overview of the selected projects is given in Table 1 . Administrative plans are reviewed to provide insight in the way CCS activities are currently addressed by national and regional government. Expert consultation is used to complement the method of literature review.

Next to already concluded or started EIA and SEA procedures also the legal framework for the Dutch EIA and SEA is analyzed, with the emphasis on the recently amended Environmental Management Act (Wet milieubeheer, 1979) and the related Environmental Impact Assessment Decree (VROM and LNV, 1994).

\section{Carbon Capture and Storage in short}

CCS is the acronym for Carbon Capture and Storage. It is an umbrella term for a wide variety of technologies which aim to reduce the anthropogenic $\mathrm{CO}_{2}$ emissions to the atmosphere. It comprises three distinctive steps. The first step is the capture process. The major part of this process is the separation of $\mathrm{CO}_{2}$ from a gas stream. This could be natural gas extracted from a well having $\mathrm{CO}_{2}$ content, which is too high to be distributed to the consumer. $\mathrm{CO}_{2}$ removal is applied widely in the hydrocarbon production industry. At present, the separated $\mathrm{CO}_{2}$ is in most projects vented into the atmosphere. It can also be captured and stored in the underground as demonstrated by Statoil and Gaz de France since 1996 and 2004, respectively (D'Hoore, 2005; Kongsjorden et al., 1998). $\mathrm{CO}_{2}$ can also be captured from power plants using carbonous fuels. Main routes are (after (IPCC, 2005)): (1) Post-combustion capture, where $\mathrm{CO}_{2}$ is se- parated from the flue gasses produced by the combustion of fuels (gas, coal, biomass). The $\mathrm{CO}_{2}$ is separated from the flue gas with the use of a liquid chemical sorbent (e.g. monoethanolamine or ammonia). (2) Pre-combustion capture, a gas stream formed by partial oxidation (gasification) or reforming of fuels contains primarily carbon monoxide $(\mathrm{CO})$ and hydrogen $\left(\mathrm{H}_{2}\right)$. In a so called watergas shift reactor the $\mathrm{CO}$ reacts with steam and yields a gas stream that consists mainly of $\mathrm{CO}_{2}$ and $\mathrm{H}_{2}$. The $\mathrm{CO}_{2}$ is then separated and the remaining gas, mainly hydrogen, is then used in the combustion process. (3) Capture after oxy fuel combustion, i.e. the combustion of carbonous fuels with oxygen instead of air. The flue gas consequently contains primarily $\mathrm{CO}_{2}$ and $\mathrm{H}_{2} \mathrm{O}$, which makes further preparations to transport and store $\mathrm{CO}_{2}$ easier. Finally, it is possible to capture (nearly) pure $\mathrm{CO}_{2}$ streams from industrial processes such as hydrogen, ammonia, steel and cement production.

The separated $\mathrm{CO}_{2}$ is treated and compressed to make it ready for the second step: transportation through a pipeline or by ship, train or truck. Transport by pipeline is considered to be the most economical feasible option in general. Transport by ship can be economically favourable if large quantities have to be transported over a long distance (>1000 km) (IPCC, 2005; p. 31).

At the injection facility, the $\mathrm{CO}_{2}$ can be recompressed so that it can be injected into the geological formation, the third step. In literature several storage media are investigated, being: deep saline aquifers; (nearly) empty oil fields, possibly with Enhanced Oil Recovery (EOR); (nearly) empty gas fields, possibly with Enhanced Gas Recovery (EGR) and deep unminable coal layers combined with Enhanced Coal Bed Methane production (ECBM) (Hamelinck et al., 2001; Van Bergen et al., 2003).

Given the scope of this article we will not discuss further details of the various technologies and storage options. These can be found elsewhere, see for instance (IPCC, 2005).

\section{Introduction to the Environmental Impact Assessment/Strategic Environmental Assessment procedure}

The main goal of the EIA is to assess and evaluate the impacts on the environment of an initiative and possible alternatives in the decision making process. One benefit of the EIA procedure is that all relevant information on environmental impacts required for various administrative decisions is gathered in a single report, the Environmental Impact Statement (EIS). This report should represent the knowledge base on environmental 
Table 1

Overview of reviewed projects

Project initiator; location Activity description

Start date EIA Status of

procedure $^{\mathrm{a}}$

Projects in the Netherlands

NUON; Eemshaven,

Maasvlakte, Sloegebied

Multi-fuel IGCC power plant possibly capture ready, 1200 MWe. Chosen

location: Eemshaven. Expected start-up in 2010-2011. $\mathrm{CO}_{2}$ capture unit not expected to be operational before 2013 .

Electrabel; Maasvlakte

Eemshaven

Eneco; Europoort,

Eemshaven

InterGen; Pernis

RWE Power AG;

Maasvlakte,

Eemshaven

Essent; Moerdijk

NAM Gasunie;

Norg/Langelo

Akzo Nobel, Gas transport

Services and NUON;

Zuidwending

NAM; Schoonebeek

NAM

NAM

Gasunie

Delta NV

Gasunie, Gas transport Services

\section{Foreign projects}

Souris Valley pipeline Ltd; USA/ Can

Latrobe Valley $\mathrm{CO}_{2}$ storage assessment project; Aus

Gorgon JointVenturers; Aus
Coal/biomass fired power plant possibly capture ready, 600-800 MWe.

Expected to be operational in 2011-2012. Maasvlakte is location of choice.

Coal/biomass fired power plant possibly capture ready, 600-800 MWe.

Natural gas fired power plant $800 \mathrm{MWe}$, two locations under consideration

Natural gas fired combined cycle power plant, $400 \mathrm{MWe}$.

Pulverized coal (biomass) fired power plant possibly capture ready,

1600 MWe gross, two locations under consideration: Eemshaven and

Maasvlakte. Expected start-up in 2012-2013.

Natural gas fired combined cycle power plant, $400 \mathrm{MWe}$.

Underground natural gas storage facility in former gas production field.

Original reservoir volume was $25 * 10^{9} \mathrm{~m}^{3}$. Working gas capacity $4.5 * 10^{9} \mathrm{~m}^{3}$.

Underground natural gas storage facility combined with the production of salt. The salt production from an underground salt layer creates a cavern in which natural gas is to be stored. The storage volume is expected to be $8 * 10^{6} \mathrm{~m}^{3}$ with a maximum injection capacity of $2.6 * 10^{6} \mathrm{~m}^{3} / \mathrm{h}$.

Enhanced oil production (2500-3000 $\mathrm{m}^{3} /$ day) project with the use of steam (6000-9000 $\mathrm{m}^{3} /$ day) produced within the project boundaries. Production with the use of $\sim 60$ wells sited on up to $\sim 20$ locations. Project includes injection of $7000-10000 \mathrm{~m}^{3} /$ day of waste water, from oil treatment and production, into empty gas fields.

Gas production facilities for gas fields located at Westbeemster, Middelie and Rustenburg. The project also includes a gas treatment facility and a pipeline of $7 \mathrm{~km}$, The project is expected to produce $2-4 * 10^{9} \mathrm{~m}^{3}$ of natural gas Natural gas production in Waddenzee area from the locations Moddergat, Lauwersoog and Vierhuizen encompasses production of $3 * 10^{6} \mathrm{~m}^{3}$ natural gas per day per location and a $22 \mathrm{~km}$ gas transport pipeline.

Natural gas transport pipeline between Grijpskerk and Wieringermeer encompasses a pipeline with $120 \mathrm{~cm}$ diameter and length of $110 \mathrm{~km}$.

Natural gas transport pipeline between Woensdrecht and the Sloegebied encompasses a pipeline with $120 \mathrm{~cm}$ diameter and length of $45 \mathrm{~km}$.

Natural Gas pipeline encompasses an offshore pipeline between Balgzand (Netherlands) and Bacton (England) the with a diameter of $92 \mathrm{~cm}$ and length of $235 \mathrm{~km}$.

Pipeline which transports $\mathrm{CO}_{2}$ from Dakota Gasification Company in USA to the existing Weyburn oil field in Canada where the $\mathrm{CO}_{2}$ is used for enhanced oil recovery. The pipeline is partly situated in Canada $(61 \mathrm{~km})$ and in the USA $(272 \mathrm{~km})$, has a maximum outside diameter of $35.6 \mathrm{~cm}$, an initial transport capacity is 5000 tonnes of $\mathrm{CO}_{2}$ per day and a maximum design pressure of $20.4 \mathrm{MPa}$.

Study on technical and economical potential of $\mathrm{CO}_{2}$ storage in oil and gas fields. The study includes a risk assessment of multiple injection locations and reservoirs. Their storage potentials range between 1 and $1200 \mathrm{Mt}$.

Gorgon gas field development, $130 \mathrm{~km}$ offshore, is expected to contain $1.1 * 10^{9} \mathrm{~m}^{3}$ of natural gas. It includes annual removal of $3.4 \mathrm{Mt} \mathrm{CO}_{2}$ from the reservoir feed gas of which $80 \%$ (2.7 Mt/year) is to be to transported with a pipeline and injected into a saline aquifer at a depth of $2 \mathrm{~km}$. The proposed 2 or 3 onshore injection locations use a total of $7 \mathrm{CO}_{2}$ injection wells.
Feb-06

Oct-06 EIS, AR ${ }^{\mathrm{b}}$ expected Mar-07

Dec-05 Not completed

Aug-06 Not completed

Apr-05 Not completed

Dec-05 Oct-06 EIS, Jan-07 completed

May-06 AR Apr-07

Jul-06 AR expected May-07

Jun-91 Jan-94

Oct-03 Nov-04

Sep-04 Nov-06

Mar-05

Mar-06

Feb-05

Apr-06

Jan-05

Dec-05

May-06

Jan-07

Sep-03

Dec-04

Oct-97

Oct-98

No EIA

started

Nov-03

Sep-05 draft EIS, Jun-06 advisory bulletin released 
Table 1 (continued)

\begin{tabular}{|c|c|c|c|}
\hline Project initiator; location & Activity description & Start date EIA & $\begin{array}{l}\text { Status of } \\
\text { procedure }^{\text {a }}\end{array}$ \\
\hline Consol Energy ECBM; USA & $\begin{array}{l}\text { Demonstration project to evaluate the effectiveness and economics of } \\
\text { methane recovery from an unminable coal seam (approx. } 384 \mathrm{~m} \text { deep) with } \\
\text { the injection and storage of } 24 \mathrm{kt} \text { of } \mathrm{CO}_{2} \text { from three surface locations. The total } \\
\text { production is estimated to be } \sim 6 * 10^{4} \mathrm{~m}^{3} / \text { day and } 4 * 10^{7} \mathrm{~m}^{3} \text { assuming } 6 \text { years } \\
\text { of operation. }\end{array}$ & Nov-01 & Mar-03 \\
\hline $\begin{array}{l}\text { ZeroGen Pty Ltd. Stanwell; } \\
\text { Queensland, Aus }\end{array}$ & $\begin{array}{l}\text { A } 100 \mathrm{MW} \text { demonstration project for a coal fired integrated gasification } \\
\text { combined or open cycle power plant with the capture of } 0.42 \mathrm{Mt} \mathrm{CO}_{2} / \mathrm{year} \text { and } \\
\text { storage in saline aquifer. The expected long term storage capacity is } 30 \mathrm{Mt} \text {. The } \\
\text { project encompasses a pipeline }(220 \mathrm{~km}) \text { and a distribution system }(48-72 \mathrm{~km}) \\
\text { from the main pipeline to the wells }(16 \text { up to } 24) \text {. }\end{array}$ & Jun-06 & Not completed \\
\hline $\begin{array}{l}\text { Bureau of Economic } \\
\text { Geology University } \\
\text { of Texas; Frio, USA }\end{array}$ & $\begin{array}{l}\text { Pilot experiment for storage of } 3.4 \mathrm{kt} \text { of } \mathrm{CO}_{2} \text { into a saline aquifer }(\sim 1500 \mathrm{~m} \\
\text { depth) located near Frio, Texas (USA). During the actual experiment } \\
1600 \text { tonnes of } \mathrm{CO}_{2} \text { were injected over a } 10 \text { day period, using one injection } \\
\text { well. Start experiment in Oct-2004 }\end{array}$ & $\begin{array}{l}\text { EA } \\
\text { published } \\
\text { Oct } 2003\end{array}$ & $\begin{array}{l}\text { FONSI }^{\mathrm{c}} \\
\text { published Oct } \\
2003\end{array}$ \\
\hline
\end{tabular}

a As of April 1st 2007.

b $\mathrm{AR}=$ Advisory review of the Environmental Impact Statement (EIS) by the Netherlands Commission for the Environmental Assessment on the quality of the report.

${ }^{c}$ A Finding of No Significant Impact (FONSI) is issued by a (US) federal agency when no significant impacts on the environment are expected due to an activity. If significant impacts are expected, a more detailed Environmental Impact Statement has to be prepared.

impacts due to the activity, and is used as reference work in the decision making process.

As the impacts assessed in the EIA are used to formulate norms and provisions in the (environmental) permit, a benefit is also that more detailed prescriptions, for instance related to external safety, can be included in the permit. Finally, an increase of public acceptance regarding the proposed activity is often achieved, due to early involvement and provision of information (Jesse and Verschuuren, 1997). This may reduce hindrance by opposing parties and prevent delaying juridical procedures ${ }^{3}$.

The Dutch EIA procedure (see Table 2) and the guidelines for setting up an Environmental Impact Statement are stated in the Environmental Management Act (EMA) (Wet milieubeheer, 1979) and Environmental Impact Assessment Decree of 1994 as amended on August 16th 2006 (EU, 1997; Staatsblad, 2006; VROM and LNV, 1994). The Dutch EIA procedure is in line with EIA Directives 85/337/EEG and the amendment $97 / 11 /$ EC of the European Union.

The SEA procedure is applicable for administrative plans which form the framework for activities subjected to EIA (judgement) obligation. The SEA is carried out by the public authority responsible for the formulation of the plan,

\footnotetext{
${ }^{3}$ An example, for a power plant a revision permit for cocombustion of biomass was issued end of 2002. On the decision for this permit a judgement duty by the competent authority on the EIA obligation applied. This decision was nullified in court (ABRS, 2004) and a new permit was finally issued four years later, end of 2006, after deliberations between the power company, province, citizens and (environmental) interest groups (Electrabel, 2006).
}

policy or programme for which an SEA is obligated. This procedure has been implemented in the Dutch Environmental Impact Assessment Decree in 2006 following EU Directives 2001/42/EG and 2003/35/EG (EU, 2001).

The latest amendment of the EMA and EIA Decree has as goal to implement the SEA procedure and to restructure both procedures such that they are complementary instruments which can be used to assess environmental impacts of decisions on various levels, respectively on the plan and project level. If the procedures are used complementary, then the emphasis will lie on the SEA procedure, as this will set the framework and creates a knowledge base for further EIA procedures. Environmental impacts are then first assessed on a higher plan level, making it possible to narrow the scope of the EIA for projects and to prevent that activities will be assessed on their environmental impacts more then once.

The EIA and SEA procedures can also be integrated into one procedure. For instance, from a concrete EIA obligated activity a SEA can be initiated. This requires, however, broadening of the scope of the research activities in the assessment if the plan forms the framework for other EIA obligated activities (e.g. other CCS projects) (VROM, 2004d). According to the government, the amendment will lead to a simplification of the current EIA procedure so that it corresponds better with the EU Directives (VROM, 2005a).

The procedural phases of both SEA and EIA are summarized in Table 2. They can be characterized as the screening phase, scoping phase, formulation phase of the 
Table 2

Simplified scheme of the SEA and EIA procedure (adapted from (VROM, 2005c))

SEA procedure $\quad$ EIA procedure

Screening phase

Determination of SEA/EIA obligation:

Direct obligation; through judgement by Competent Authority (CA); Voluntary SEA/EIA

Scoping phase

- Public notification of the intention to formulate a plan by CA

$-$

- Authority consults appropriate/affected public authorities on the scope and detail of environmental report

Formulation phase of environmental report

- CA formulates environmental report

- Description of current state of the environment and the environmental impacts of the business as usual scenario

- Describe alternatives to the plan and their impacts

- Publication of preliminary plan and environmental report

\author{
- Initiator announces intention to undertake EIA obligated \\ activities to CA \\ - Publication of intention by CA \\ - Public consultation \\ - Advise on guidelines for the environmental report by the Netherlands \\ Commission for EIA (NCEIA) \\ - Formulation of guidelines and publication by Competent Authority (CA)
}

Advise and decision making phase

- Public consultation facilitated by CA

- Consultation of concerned public authorities

- Public consultation facilitated by CA

- Consultation of Advisors stated in the law

- Advice by the NCEIA on the quality of the environmental report ${ }^{\text {a }}$

- CA adopts plan

- NCEIA advises CA on quality of environmental report

- Publication of final decision by CA

- CA formulates evaluation plan (period and method)

- CA formulates evaluation plan (period and method)

\section{Evaluation phase}

- CA evaluates environmental impacts

- CA evaluates environmental impact

Note that various procedural steps of the permitting/formulation of a plan procedure are executed parallel with the SEA and EIA procedures and are not included in this table. $\mathrm{CA}=$ Competent Authority; $\mathrm{BPEO}=$ Best Practicable Environmental Option; NCEIA = Netherlands Commission for EIA.

a This is only obligated for plans which affect areas following the Bird/Habitat Directives and National Ecological Network.

EIS/environmental report, advice and decision making phase and the evaluation phase. In this article we will focus merely on the screening and scoping phase.

\section{Screening phase for the procedures}

\subsection{CCS projects and Environmental Impact Assessment}

The screening phase in the Netherlands has as goal to determine whether an SEA or EIA has to be started for respectively the plan or project. The purpose of this section is to discuss if a CCS project would be EIA obligatory using current EIA thresholds.

Not all projects or activities (which require an environmental permit) are obligated to execute an EIA in preparation of an administrative decision. In annexes C and D of the Dutch EIA decree (VROM and LNV, 1994) categories of activities are defined. In Table 3 it is depicted which categories are relevant for CCS projects. For each category of activities thresholds are set (column 3), above which projects are directly obligated (annex $\mathrm{C}$ categories) to undergo an EIA.

There are also activities which require a decision from the competent authority (column 4), which in the screening phase determines the necessity of an EIA. These are called judgement obligatory activities (annex D categories). Furthermore, the government on the regional level (provinces) can define lower thresholds for certain activities. Finally, there is the possibility to perform a voluntary EIA. When the project initiator chooses to execute an EIA it must fulfill the requirements set as if it is an obligatory EIA.

In column 6 of Table 3 the formal decisions are described that trigger the EIA procedure. In the case of 
Table 3

EIA/SEA obligated activities and plans in the Netherlands (VROM and LNV, 1994) and (Staatsblad, 2006)

\begin{tabular}{|c|c|c|c|c|c|}
\hline $\begin{array}{l}\text { Step in CCS } \\
\text { chain }\end{array}$ & Activity & $\begin{array}{l}\text { Threshold above which } \\
\text { EIA/SEA is obligated }\end{array}$ & $\begin{array}{l}\text { Threshold above which competent } \\
\text { authority has to decide on the EIA/ } \\
\text { SEA obligation }\end{array}$ & Plans $^{a}$ & Decisions for which the EIA is concluded \\
\hline All & $\begin{array}{l}\text { Plans which affect areas following } \\
\text { the } \\
\text { Bird Habitat Directive and National } \\
\text { Ecological Network }\end{array}$ & \multicolumn{2}{|l|}{$\begin{array}{l}\text { Only SEA obligated: plans that contain decisions on projects that } \\
\text { separately or in combination with other projects or operations can have } \\
\text { significant impact on the sensitive area concerned. (Art. 19f, (1) } \\
\text { of the Nature Preservation Act) }\end{array}$} & Any & Not applicable. \\
\hline Power plant & $\begin{array}{l}\text { The construction, alteration or } \\
\text { expansion of an installation } \\
\text { for the production of electricity, } \\
\text { steam of heat (not nuclear). }\end{array}$ & Capacity $\geq 300$ MWth & $\begin{array}{l}\text { - Capacity } \geq 200 \text { MWth } \\
\text { Alteration or expansion: } \\
\text { - Increase capacity of } \geq 20 \% \text {. } \\
\text { - Change of fuel mix. }\end{array}$ & $\mathrm{I}-\mathrm{VI}$ & $\begin{array}{l}\text { The decisions on which part } 3.4 \text { of the GALA } \\
\text { and Section } 13.2 \text { of the EMA applies. }{ }^{c}\end{array}$ \\
\hline Transport & $\begin{array}{l}\text { The construction, alteration or } \\
\text { expansion of a pipeline for the } \\
\text { transportation of oil, } \\
\text { gas or chemicals. }\end{array}$ & $\begin{array}{l}\text { Diameter }>80 \mathrm{~cm} \text { and } \\
\text { Length }>40 \mathrm{~km} .\end{array}$ & $\begin{array}{l}\text { A pipeline which is situated or } \\
\text { projected with a length } \geq 1 \mathrm{~km} \text { in } \\
\text { a designated sensitive area. }\end{array}$ & $\mathrm{I}-\mathrm{VI}$ & $\begin{array}{l}\text { The decision, meant in art. } 94 \text { (1) and art. } 95 \text { of } \\
\text { the mining decree or the decision, meant in } \\
\text { art. 2, of the Public Works Act. }\end{array}$ \\
\hline \multirow[t]{5}{*}{ Storage } & $\begin{array}{l}\text { Extraction of oil and natural gas } \\
\text { (in case of enhanced oil/gas } \\
\text { recovery) }\end{array}$ & Gas $>500000 \mathrm{~m}^{3} /$ day & $\begin{array}{l}\text { When activity involves the } \\
\text { alteration or expansion in } \\
\text { a designated sensitive area and } \\
\text { involves: } \\
\text { - Extension of the surface area } \\
\text { with } \geq 5 \text { ha. } \\
\text { - Adding/altering installations }\end{array}$ & I-VI & $\begin{array}{l}\text { Art. } 40 \text { 2nd section of Mining Act or the decisions } \\
\text { on which part } 3.4 \text { of the GALA and Section } \\
13.2 \text { of the EMA applies. }\end{array}$ \\
\hline & $\begin{array}{l}\text { Deep drilling or altering or } \\
\text { expanding a current activity for } \\
\text { searching or extraction of salt, } \\
\text { gas or oil. }\end{array}$ & Not applicable. & No threshold set. & I-VI & $\begin{array}{l}\text { Art. } 40 \text { of Mining Act or the decisions on which } \\
\text { part } 3.4 \text { of the GALA and Section } 13.2 \text { of the } \\
\text { EMA applies. }\end{array}$ \\
\hline & $\begin{array}{l}\text { Establishing an installation for } \\
\text { storing } \\
\text { of non-dangerous wastes in the } \\
\text { underground. }\end{array}$ & $\geq 500000 \mathrm{~m}^{3}$ in total. & Not applicable. & I-VI & $\begin{array}{l}\text { The decisions on which part } 3.4 \text { of the GALA } \\
\text { and Section } 13.2 \text { of the EMA applies. }\end{array}$ \\
\hline & $\begin{array}{l}\text { Altering or expanding a waste } \\
\text { management installation. }\end{array}$ & Not applicable & $\begin{array}{l}\text { - Dumping or storing } \geq 250.000 \mathrm{~m}^{3} \\
\text { in total. } \\
\text { - Managing } 100 \text { tonne waste/day }\end{array}$ & $\mathrm{I}-\mathrm{VI}$ & $\begin{array}{l}\text { The decisions on which part } 3.4 \text { of the GALA } \\
\text { and Section } 13.2 \text { of the EMA applies. }\end{array}$ \\
\hline & $\begin{array}{l}\text { The ascertainment of the policy } \\
\text { concerning waste management }\end{array}$ & $\begin{array}{l}\text { Concerning the: } \\
\text { - Method of waste processing. } \\
\text { - The permanent placement of waste on or under the ground. } \\
\text { - Site selection or the creation of facilities for waste } \\
\text { management. }\end{array}$ & Not applicable. & VII-A & $\begin{array}{l}\text { The adoption of Plan VII-B or the decisions on } \\
\text { which } \\
\text { part } 3.4 \text { of the GALA and Section } 13.2 \text { of the EMA } \\
\text { applies or the adoption of plan IV or V that contains } \\
\text { provisions for the activity. }\end{array}$ \\
\hline
\end{tabular}

${ }^{\text {a }}$ Plans for which the SEA is concluded are: I = national spatial policy plans (art. 2(a) Spatial Planning Act); II = regional spatial plan (art. 4(a) Spatial Planning Act); III = structure plan municipality (art. 7 Spatial Planning Act); IV = (local) land use plan (art. 10 Spatial Planning Act); V = implementation and/or alteration of (local) land use plan (art. 11(1) Spatial Planning Act); VI = regional structure plan (art. 36(c) Spatial Planning Act); VII-A = National Waste Management Plan (art 10.3 in conjunction with art 10.7 (2)(a) of Environmental Management Act); VII-B = National Waste Management Plan (art 10.3 in conjunction with 10.7 (2)(b) ) of Environmental Management Act).

${ }^{\mathrm{b}}$ Installations for the removal of nitrogen and sulphur.

c Section 3.4 of the General Administrative Law Act (GALA) applies on the public preparation of decisions if that has been stipulated at legal regulation or laid down by order of the governing body. Section 13.2 of the Environmental Management Act (EMA) regulates how the decision, concerning a license application or an exemption [for which] an Environmental Impact Statement must be made, is to be executed. 
power plants these are often the decisions on a permit under the Environmental Management Act and Pollution of Surface Waters Act. In case of a pipeline the decision on a permit under the Mining Act or Public Works Act often triggers the EIA obligation. For $\mathrm{CO}_{2}$ storage the decision on a permit under the Mining Act or Environmental Management Act will be the decision which requires the EIA. Also, a (partial) revision of a municipal zoning plan or exemption from provisions in that plan can be the decision for which the EIA is necessary.

Next to the decision for which the EIA is required, a wide variety of other decisions on permits and exemptions, which are needed for the project, can be included in the EIA procedure to streamline the decision making process. For large infrastructural projects it is possible to apply the 'state project procedure' (rijksprojectenprocedure) (IEA, 2006). The procedure is executed by the national government and coordinates parallel decision making processes. It coordinates the timing of consultation and decisions of administrative bodies on various levels (national, provincial and municipal). Through coordination also public consultation and possibilities for appeal is synchronized for these decisions. This state project procedure has already been applied on five wind energy projects for which one EIA is being executed and on the extension of the national natural gas infrastructure constituting of various segments. For each segment a separate EIA is executed.

\subsubsection{Power plants}

At the end of 2005 and early 2006 several EIA procedures (see Table 1) started for new power plants in the 800-1200 MWe range. In these projects $\mathrm{CO}_{2}$ capture is considered a possible alternative for the future and thus these power plants may be designed capture ready (Commissie MER, 2006f; Commissie MER, 2006g; Electrabel, 2005; KEMA, 2006). Capture ready means that the new installations and its location are designed under consideration of the possibility of adding a $\mathrm{CO}_{2}$ capture installation at a later date (Commissie MER, 2006g; Electrabel, 2005). There is also a project proposal to build a demonstration power plant, the so called Zero Emission Power Plant (ZEPP), with $\mathrm{CO}_{2}$ capture $(\sim 0.3 \mathrm{Mt}$ per year $)$ with a net generating capacity of $50 \mathrm{MWe}(\sim 170 \mathrm{MWth})$ based on oxy fuel combustion (SEQ et al., 2005). The goal is to inject the $\mathrm{CO}_{2}$ formed by the combustion of natural gas into a nearly depleted gas field and possibly obtain natural gas back in the process, i.e. Enhanced Gas Recovery (Buyze et al., 2004; SEQ et al., 2005).

A review of literature studies on the concepts for power plants with $\mathrm{CO}_{2}$ capture indicates that in general no new power plants with capture facilities are expected to be build in the size range below 300 MWth (IPCC, 2005). In that case, Table 3 shows that a power plant with $\mathrm{CO}_{2}$ capture is highly likely to be EIA obligatory or that the competent authority has to decide on its obligation.

As indicated in Table 3 the ZEPP project will not be EIA (judgement) obligatory regarding the size of the power plant. The addition of a capture installation to an existing power plant is not EIA (judgement) obligatory if it does not involve the addition of a capacity of $200 \mathrm{MWth}$ to the power plant, an increase of capacity by more than $20 \%$, or a change in the fuel mix. Adding a capture installation will have an effect on the design and operation of the plant and will change the risks, emission profile and consequently the environmental impacts of the plant. Therefore, it would be logical that the addition of a $\mathrm{CO}_{2}$ capture installation would at least require a decision by the competent authority on the EIA obligation.

\subsubsection{Transport by pipeline}

Experience with the transport of $\mathrm{CO}_{2}$ is recently expanded with the so called OCAP (Organic Carbon dioxide for Assimilation of Plants) project. In this project $300 \mathrm{kt} \mathrm{CO}_{2}$ per year is captured from a refinery and transported to horticulture through a part of an already existing oil pipeline of $85 \mathrm{~km}$.

The EIA thresholds for the transport of $\mathrm{CO}_{2}$ through pipelines are based on the dimensions (diameter $>80 \mathrm{~cm}$ and length $>40 \mathrm{~km}$ ) and route of the pipeline. The OCAP project makes use of pipelines with a maximum diameter of $\sim 65 \mathrm{~cm}$, well below the current threshold. The project is consequently also not EIA obligated. The $\mathrm{CO}_{2}$ pipeline for the EOR project at Weyburn (Canada) has a maximum outside diameter of $35.6 \mathrm{~cm}$ and a total length of $333 \mathrm{~km}$ (National Energy Board, 1998; Wilson and Monea, 2004). Another pipeline, which is in the design phase, is the pipeline of the Latrobe valley project in Australia (Hooper et al., 2005). The onshore part of one design variant encompasses a pipeline of $95 \mathrm{~km}, 30.5 \mathrm{~cm}$ outside diameter and a daily transport capacity of about 5500 tonnes of $\mathrm{CO}_{2}$. This project and the $\mathrm{CO}_{2}$ pipeline for the EOR project at Weyburn (Canada) indicate that the EIA thresholds for pipeline transport given in Table 3 will not be exceeded when realized in the Netherlands.

Constructing a 1000 MWe coal fired power plant with $\mathrm{CO}_{2}$ capture ${ }^{4}$ with a dedicated pipeline between

\footnotetext{
${ }^{4}$ Based on the following assumptions: 1000 MWe net capacity including $\mathrm{CO}_{2}$ capture; $1.02 \mathrm{~kg}$ captured $\mathrm{CO}_{2}$ per $\mathrm{kWh} ; 85 \%$ capacity factor; results in an annual flow of $7.55 \mathrm{Mt}$; using the formula, which is derived from (Hooper et al., 2005), to calculate the outside diameter in centimetres $y=23.22^{*}$ (flow of $\mathrm{CO}_{2}$ in $\mathrm{Mt} /$ year) ${ }^{0,3886}$ yields $51 \mathrm{~cm}$ outside diameter.
} 
plant and a storage site would result in a flow of $7.5 \mathrm{Mt}$ $\mathrm{CO}_{2}$ per year. According to our estimates ${ }^{4}$ the pipeline in this case would have an outside diameter of about $50 \mathrm{~cm}$. This implicates that also in this case the transport of $\mathrm{CO}_{2}$ would not require an EIA in the Netherlands if it does not cross a sensitive area. $\mathrm{CO}_{2}$ pipelines with a length exceeding $40 \mathrm{~km}$ are expected to be EIA obligated from a transport capacity of about $24 \mathrm{Mt} /$ year.

\subsubsection{Storage}

The $\mathrm{CO}_{2}$ injection project by Gaz de France, mentioned earlier, was exempted from performing an EIA as it is a small scale demonstration project ( $20 \mathrm{kt} /$ year) of relative short duration ( $\sim 3$ years). Currently, $\mathrm{CO}_{2}$ is not specifically mentioned in the EIA decree and no thresholds are defined for its underground storage. Some thresholds may be applicable (see Table 3 ) based on the assumption that $\mathrm{CO}_{2}$ is regarded as a non-dangerous waste (see also (CRUST Legal Task Force, 2001)). However, the discussion on the legal status of $\mathrm{CO}_{2}$ when injected into the underground is not concluded yet and is the matter of national and international debate. Its outcome is important as it determines if and how EIA/ SEA legislation as well as other laws and regulations is to be applied on $\mathrm{CO}_{2}$ storage. For instance, when $\mathrm{CO}_{2}$ is to be regarded as a dangerous waste, then no threshold applies and an EIA is obligated in any case. Another possibility is that $\mathrm{CO}_{2}$ is to be regarded as an asset, then again other thresholds apply.

First we assume that $\mathrm{CO}_{2}$ is a non-dangerous waste. $\mathrm{A} \mathrm{CO}_{2}$ storage installation ${ }^{5}$ for the injection of $\mathrm{CO}_{2}$ into the underground is EIA obligatory when storing more then $500000 \mathrm{~m}^{3}$ of $\mathrm{CO}_{2}$.

Assuming a density ${ }^{6}$ of 0.6 tonne $/ \mathrm{m}^{3}$ this threshold equals $0.3 \mathrm{Mt}$ of $\mathrm{CO}_{2}$ in total. This equals the annual production of the proposed ZEPP in Drachten and the biweekly production of a 1000 MWe coal fired power plant. Thus, this threshold is highly likely to be exceeded by any commercial scale storage project.

In the Netherlands, underground $\mathrm{CO}_{2}$ storage is also EIA and SEA obligated (VROM, 2005b) through the formulation of governmental policy concerning treatment of waste in the National Waste Management Plan (NWMP). This plan contains three parts. The first part (VROM, 2004b) presents a policy framework

\footnotetext{
${ }^{5}$ A storage installation includes both above and underground parts. (CRUST Legal Task Force, 2001).

${ }^{6}$ Density is depended on the pressure and temperature of the $\mathrm{CO}_{2}$. Here we assume $\mathrm{CO}_{2}$ storage at $1000 \mathrm{~m}$ depth, at a pressure of 100 bar, with $25^{\circ} \mathrm{C} / \mathrm{km}$ pressure gradient and a temperature of $15^{\circ} \mathrm{C} \mathrm{s}$ at the surface.
}

describing the main principles of the national policy on waste management (plan VII-A in Table 3), and is SEA obligated. The second part describes the waste management policy for various sectors, including the energy sector. For different categories of substances, waste handling options are discussed and minimum handling standards are given. The third part deals with capacity planning for waste treatment, using incineration and (underground) deposition of waste (VROM, 2004c).

At the time Parts II and III of the NWMP were formulated, they were EIA obligated (Afval Overleg Orgaan, 2002a). In the EIA different waste handling options were compared, using the methodology of Life Cycle Assessment (LCA) (Afval Overleg Orgaan, $2002 \mathrm{~b}$ ). Storage of $\mathrm{CO}_{2}$ into the underground was neither included in the NWMP nor in the EIA.

Other thresholds might be applied when $\mathrm{CO}_{2}$ is considered an asset which is used to enhance the recovery of oil or gas from near empty reservoirs (respectively EOR and EGR) or the recovery of methane from coal seams by injection of $\mathrm{CO}_{2}$ (ECBM). For EOR and EGR the thresholds apply as formulated for activities which involve the extraction of natural gas and oil or the deep drilling required for the extraction or search for these resources (see Table 3). The EIA obligation for ECBM is discussed already by Van Bergen et al. (2003), who concluded that it is unclear to determine the EIA obligation for such projects. This is mainly due to various possible interpretations of the law, for instance: should $\mathrm{CO}_{2}$ be regarded as a waste or asset and should the recovered methane from ECBM be regarded as natural gas or not? When the methane is considered not to be analogous to natural gas, then the thresholds for the extraction of natural gas do not apply.

An offshore installation for the storage of $\mathrm{CO}_{2}$ which is situated beyond the Dutch territorial sea (12 miles zone) does not require an environmental permit under the Environmental Management Act. The installation does require a mining environmental permit in accordance with the Mining Act (Mijnbouwwet, 31 October 2002). On this permit the EIA decree applies, such that an EIA is (judgement) obligated when the thresholds are met. For the permit for offshore pipelines the EIA decree similarly applies.

\subsection{Plans for CCS and the Strategic Environmental Assessment}

An SEA is obligated for governmental policies, plans and programs (see Table 3) when the plan: (1) has possible impacts on areas following from the nature preservation act (art 10a) in accordance with the Bird and Habitat 
Directives of the EU (EC, 1979; EC, 1992) or (2) when the plan contains concrete decisions on EIA obligated activities. The plans subjected to a SEA procedure are, amongst others, plans based on the Spatial Planning Act (plans I-VI in column 5 of Table 3). They include key planning decisions as well as regional and municipal zoning plans. The environmental impacts related to the plan must also be assessed if the plan provides a substantial framework for future EIA obligated activities (VROM, 2005b). Examples are pronouncements in the plan on the appointment of possible locations or routes, or the consideration of alternative locations or routes. This is thus highly dependent on the level of detail of the plan. Here we will present and discuss some plans relevant for CCS on the national and regional level.

\subsubsection{Storage}

The first example is the national policy on waste which is part of the national waste management plan (VII-A in Table 3). An important statement in the NWMP is (VROM, 2004b; Section 18.4, p.207): "The underground, in principle, is not destined to store waste or components of waste not directly originating from the underground. [It is] only acceptable if the stored waste is reclaimable." This has been elaborated further on the reinjection of (polluted) production water, which is a waste stream from processes in the oil and gas production industry. For re-injection a permit can be allowed if re-injection is proven to be environmental or significantly economical favourable compared to other waste processing options (VROM, 2004b). By the end of $2006 \mathrm{CO}_{2}$ storage was proposed to be added to Section 18.4 of the NWMP with the notion that the conditions mentioned above do not apply to $\mathrm{CO}_{2}$ storage. Under what conditions and whether $\mathrm{CO}_{2}$ storage is allowed will probably be formulated in the succeeding SEA obligated plan, the NWMP II, taken into account the criteria stated in EU Directive 1999/31/ EC on the landfill of waste and Council Decision 2003/ $33 / \mathrm{EC}$ on establishing criteria and procedures for the acceptance of waste at landfills (see for more elaboration Section 6) (VROM, 2006).

\subsubsection{Transport by pipeline}

An example for a spatial plan is a National Spatial Planning Key Decision ${ }^{7}$ such as The National Structure

\footnotetext{
${ }^{7}$ In the new Spatial Planning Act, which is planned to become effective at the end of 2007, the National Spatial Planning Key Decisions and structure plans on the municipal and regional level are to be replaced by structure visions. This structure vision is a strategic policy document on the spatial development of a certain area.
}

Plan for Pipelines (SBUI) published in 1984. The SBUI provides a long term vision of the government on transportation of goods by pipelines. The plan focuses on the spatial implications of a national network of main transport lines used to connect industrial areas. In the SBUI the government envisions pipeline strips (45$70 \mathrm{~m}$ wide) which are to be integrated in regional and local spatial plans to reserve space for future pipelines. $\mathrm{CO}_{2}$ pipelines are not foreseen and included in the SBUI (EZ et al., 1982-1984). Enthoven (2004) reviewed the national policy on pipelines and recommended that $\mathrm{CO}_{2}$ transport by pipelines should be considered when formulating a new long term vision for pipelines in the Netherlands. Such a long term structure vision ${ }^{7}$ for $\mathrm{CO}_{2}$ pipelines is possibly to be propounded in a new policy plan concerning pipelines, the Policy Document Pipelines, before the end of 2008 when the validity of SBUI expires. Enthoven (2004) also mentioned the option to integrate the structure visions for pipelines and for electricity supply.

\subsubsection{Power plants}

Another example is the second National Structure Plan for the Electricity Supply (SEV II) published in 1994. The main purpose of the SEV is to provide the spatial and environmental conditions for the planning of electricity utilities. In the SEV II locations of large scale power plants, installed capacity per fuel and routes of electricity transmission lines are envisioned for 2010. $\mathrm{CO}_{2}$ capture was considered a technical option to reduce $\mathrm{CO}_{2}$ emissions from natural gas combined cycle (NGCC) power plants. It was included in the obligatory plan-EIA for the SEV II which had as goal to assess the environmental impact of various electricity supply options (centralized versus decentralized, conversion technologies, fuel mix) in relation with various demand scenarios. In the SEV II (1992-1994), $\mathrm{CO}_{2}$ capture was considered a non-mature and economically unfeasible technology at that time. Therefore, it was neither taken into account when planning new capacity per fuel nor during the selection of locations for power plants (EZ and VROM, 1994). Currently the first phase of the new National Structure Plan for the Electricity Supply (SEV III) is being formulated. The plan contains pronouncements on possible locations for power plants and provides a framework for future EIA obligated activities. The plan is thus SEA obligated. An SEA and an appropriate assessment (following the EU Bird and Habitat Directives) are currently being formulated. Currently it is inconclusive whether and at what level of detail the SEA will contain comparison of power plant design alternatives with $\mathrm{CO}_{2}$ capture and if and 
how other CCS components, transport and storage, are included in the scope.

\subsubsection{Regional plans}

At the province level $\mathrm{CO}_{2}$ storage is mentioned in regional spatial plans. For instance, the province of Groningen (Bolhuis et al., 2000) states in its regional environmental plan $^{8}$ that the deep underground can be used to store $\mathrm{CO}_{2}$. The province of Friesland awaits further information on the merits and disadvantages of $\mathrm{CO}_{2}$ storage before they form an opinion (Gedeputeerde Staten van Friesland, 2005). Although in both plans $\mathrm{CO}_{2}$ storage is mentioned it has not been incorporated in the environmental report (following the SEA procedure) accompanying the (revised) plans (Niekerk et al., 2005; Province of Friesland, 2005).

The province of Drenthe stated that in preparation of the new regional environmental plan a study on the possible functions of the underground is to be concluded in 2007 (Provincie Drenthe, 2006). This should lead towards an integral policy for the underground. The province had already commissioned a study by TNO in which several locations for earth heat and four candidate fields for $\mathrm{CO}_{2}$ storage in empty gas reservoirs were opted (TNO, 2005).

\section{Scoping phase for the procedures}

The scoping phase of the procedure starts with the public notification (the inception note) of the intent to formulate a plan or to undertake an activity that is SEA or EIA obligated, respectively (see Table 2). In this notification the initiator or competent authority describes the goal of the project or plan, the EIA or SEA obligation of the activity or plan, legal settings and appropriate competent authority or authorities, the alternatives to carrying out the activity or plan and the environmental impacts which are going to be assessed in the procedure and published in the environmental report.

Following the public notification in an EIA procedure, interested parties (e.g. the general public and NGO's) and all formal parties, including formal advisors ${ }^{9}$ are allowed

\footnotetext{
${ }^{8}$ The regional environmental plan is the integration of, among others, the regional spatial plan and environmental policy plan.

${ }^{9}$ Formal advisors are the Inspector for public health and environmental affairs or the Ministry of Housing Spatial Planning and the Environment; the Directors of involved departments of the Ministry of Agriculture, Nature and Food Quality and advisors in the framework of the decision in question. The latter advisors are thus dependent on the decision that has to be taken by the competent authority. They are for instance: the Inspector-General of mines, Provincial executives of the relevant provinces and the Municipal executive.
}

to advise the competent authority on the guidelines to be set for the report. An additional step in the Dutch EIA procedure is the consultation of the Netherlands Commission for EIA (NCEIA). This independent commission then advises the competent authority on the guidelines for the report by issuing an Advice on Guidelines (AoG).

In the present SEA procedure the scoping phase is highly facultative. It primarily constitutes of deliberation on the scope between the initiator and (other) administrative bodies which are involved in the preparation of the plan. In addition, the initiator may choose to exclude the independent commission (the NCEIA) and consultation of the public from the scoping phase.

The relevance of the scoping phase and the participation of the actors involved are significant, as it creates focus and broad acceptance of the structure of the procedure and following report. In 2002, a commission to the European Parliament and Council reviewed the implementation of the EIA Directive in EU member states. The review quotes literature pleading for public involvement in the scoping process, though the explicit recommendation to include participation in the scoping phase is absent (European Commission, 2002; p. 52). An evaluation of the Dutch EIA procedure pointed out that the scoping phase should be deployed more actively (Novioconsult, 2003). This ensures that no unnecessary information will be assessed and included in the EIS and that the scope of the procedure and EIS is not a subject of debate or even juridical conflicts afterwards (Milieuloket, 2005; Verschuuren, 2004). In addition, the NCEIA has pronounced that exclusion of their advice from the procedure may lead to the reduction of the quality of the report and may cause lengthy juridical procedures (Commissie MER, 2005d).

One question which has to be answered in the scoping phase of both procedures for CCS projects in the Netherlands is: which alternatives to the CCS activities should be assessed in the procedure? Here we will discuss some approaches possible for answering this question for the EIA and SEA procedures for CCS activities. This question is answered based on experiences with SEA or EIA procedures for CCS activities abroad and analogue projects for which an EIA is performed in the Netherlands (see Table 1).

\subsection{Scoping in SEA procedures}

An SEA has been concluded for the structure vision Zuiderzeelijn. This is the first SEA in the Netherlands in which a CCS activity is included and provides insight in the wide scope that may be applied in an SEA. The goal 
of this structure vision is to assess the usefulness and necessity of a high speed transport connection, the Zuiderzeelijn, from the west of the Netherlands to the north. This transport connection is suggested to improve the regional economy of the North. Within the structure vision several alternatives are opted. These alternatives include also non-transport options to realize the same goal, the improvement of the regional economy. The ZEPP mentioned earlier is part of a package of possible non-transport projects selected for the realization of the goal (Klooster et al., 2006). In the (voluntary) AoG for the SEA (Commissie MER, 2005e) the NCEIA advised to select alternatives on two levels of decision making. The first, and more abstract, global level deals with the selection of alternatives appropriate for fulfilling the goal of the plan in a broad sense. The assessment of environmental impacts should not go into details and should only roughly sketch the consequences of the selected alternatives. In this case it includes the transport, non-transport and no action alternatives. Then, at the second level, concrete alternatives should be assessed on a more detailed level in order to make comparison of the alternatives on their environmental impacts possible. Special care on the second level should be given to the criteria (including environmental criteria) on which the comparison of alternatives is based. This comparison should possibly yield a preferred alternative. It also should include a discussion on which criteria are decisive in the comparison and which environmental effects of the alternatives are significant and consequently should get more attention in further analyses. The NCEIA recommends that this approach is to be considered in all future SEA's (Commissie MER, 2006i).

At least two SEA procedures in other countries were started for CCS and provide insight into the possibilities for the scope of both procedures in the Netherlands. The first is an SEA for CCS by the power generating industry. Vattenfall (Eriksson et al., 2006) assessed the environmental impacts of various power plant alternatives for capturing $\mathrm{CO}_{2}$ and evaluated the potential environmental consequences of transport options (ship, truck, pipeline and train). To address the safety of $\mathrm{CO}_{2}$ storage in a geologic reservoir they chose three scenarios: no leakage of the reservoir, long term low leakage and short term high leakage. The comparison was extended by adding no action alternative as reference for the CCS alternatives. In another publication by Vattenfall (2005) it was added that other climate change mitigation options should be assessed as well.

The second is an SEA started in the USA for CCS from a national policy programme perspective (NETL, 2004a; NETL, 2004b; NETL, 2003b). For the implementation of the Carbon Sequestration Program a Programmatic Environmental Impact Statement (PEIS) was planned to be drafted. The PEIS would be the follow up paper of a public scoping report. In the scoping report potential environmental impacts of a wide variety of alternatives for sequestering $\mathrm{CO}_{2}$ as investigated within the DOE Carbon Sequestration Program are identified and discussed. The alternatives encompass carbon capture, geologic, oceanic and terrestrial sequestration and monitoring, mitigation and verification technologies. In the PEIS the impacts would be addressed from a technology-specific perspective on a regional to national scale. Site specific impacts will be assessed in impact assessments for individual projects. The PEIS would then be used as a framework for EIA's for site specific projects in the future. Recently, the preparation of the PEIS has been cancelled as it "would not direct any programmatic decisions" and activities within the programme and, moreover, other research efforts are already providing insight into the subject (US DOE, 2007).

\subsection{Scoping in foreign EIA procedures on CCS}

In Canada an environmental assessment ${ }^{10}$ for a $\mathrm{CO}_{2}$ pipeline to the $\mathrm{CO}_{2}$-EOR project in Weyburn was conducted (see also Table 1). The executing competent authority, the National Energy Board, requested public comment on the scope of the assessment. An Environmental NGO suggested that cumulative effects of the $\mathrm{CO}_{2}$-EOR project at Weyburn and the US part of the pipeline should be considered and consequently they should be included in the scope of the assessment. Finally, the competent authority approved the pipeline project without expanding the scope of the assessment as there was no informed concern with environmental impacts of the $\mathrm{CO}_{2}$-EOR project to justify this. Furthermore, expansion "would have triggered a "comprehensive study" which would have required additional time and expenses from the project proponent and could have delayed the project significantly (Province of Saskatchewan, 2000).

The environmental assessment carried out for the pilot experiment near Frio (USA) included the following alternatives: an alternate location in the same basin, an alternate basin (and location), injection in oil or gas field and the no action alternative (NETL, 2003a).

\footnotetext{
${ }^{10}$ In the EIA procedure in Canada first the environmental assessment is formulated. Then the competent authority decides whether the projects will have significant impacts on the environment. If not, a more stringent Environmental Impact Statement is not required anymore.
} 
Alternatives considered in the environmental assessment for a $\mathrm{CO}_{2}-\mathrm{ECBM}$ field test in West-Virginia (USA) were, apart from no action, vertical drilling as alternative to the proposed directional or horizontal drilling of wells for injection of $\mathrm{CO}_{2}$ and production of CBM. The environmental assessment comprehends all activities and components within the project, such as: the surface facilities for intermediate $\mathrm{CO}_{2}$ storage, injection of the $\mathrm{CO}_{2}$ and removal of $\mathrm{CO}_{2}$ from the produced gas stream. The required infrastructure such as roads for $\mathrm{CO}_{2}$ transport by truck and pipelines with compressors to transport the produced gas were also within the scope of the assessment (Consol Energy inc., 2002; NETL, 2005).

The alternatives assessed in the draft EIS for the Gorgon gas development project in Australia comprise location alternatives on a regional level. Subsequently, site specific location alternatives and also alternative routes for gas pipelines were assessed. Also, a no action alternative was discussed. Within the project the $\mathrm{CO}_{2}$ capture and injection were also compared with other alternatives to reduce or prevent greenhouse gas emissions into the atmosphere. These were: selling the captured $\mathrm{CO}_{2}$ as a feedstock to other industries, to support the use of natural gas as transport fuel, terrestrial carbon sequestration (re-vegetation, commercial forestry, reduced land clearing and land rehabilitation plantings), to induce change in the fuel mix of other industries and to support renewable energy technology development and implementation (Chevron Australia, 2005b; p. 601) (Chevron Australia, 2005a).

Another project in Australia (Latrobe Valley) is a study on the technical and economical potential and risks of storing 2-50 Mt/year of $\mathrm{CO}_{2}$ in oil and gas fields located both on- and offshore. The studied reservoirs were located between 20 and more than $200 \mathrm{~km}$ from the $\mathrm{CO}_{2}$ source, which are energy facilities. The study focuses on the storage assessment which includes a regional geological evaluation to identify and rank potential environmentally sustainable injection sites. High ranked sites were subjected to a detailed geological study. Using data on injectivity, containment and capacity, Hooper et al. (2005) predicted economical characteristics and the fate of $\mathrm{CO}_{2}$ in the underground after injection. This included a risk assessment for three reservoirs.

For the planned ZeroGen demonstration project in Queensland (Australia) the formulation of the draft EIS has recently started (end 2006) and will include feasible alternatives to the project and its components. This will incorporate site and route selection for the power generation facility, $\mathrm{CO}_{2}$ pipeline, $\mathrm{CO}_{2}$ storage area and injection facility (The Coordinator-General, 2006).

\subsection{Scoping in EIA procedures in the Netherlands}

In Table 4 an overview of alternatives is given that are assessed in the reviewed Dutch EIA procedures. The individual procedures do not include all the alternatives, and the selection of alternatives is highly project specific. In the sections below, analogue projects to CCS components are discussed separately.

\subsubsection{Scoping in EIA for power plants in the Netherlands}

Advises on the guidelines (AoG) for several EIA's issued by the NCEIA for Natural Gas fired Combined Cycle power plants (NGCC) focussed on alternatives for flue gas cleaning (DeNox installation), various turbine classes with different performance, separate firing of (biomass)fuels with steam-side integration, condenser cooling variants, variants for partial load versus full load operation, design variants for the main building and variants describing the use of steam and/or heat for, respectively, industrial processes and district heating (Commissie MER, 2005b, 2005c, 2006h, 2006a).

For an EIA procedure for a 1200 MWe multi-fuel (coal, natural gas and biomass) input IGCC power plant initiated by NUON, and to be build in Eemshaven, the scope involves the comparison of the proposed installation with a multi-fuel fired fluidized bed combustion boiler combined with a NGCC (natural gas fired), and a NGCC combined with a pulverized coal boiler with biomass co-firing (Commissie MER, 2006e, 2006f, 2006g). Other alternatives suggested were: a discussion of partial load versus full load operation, gasification with oxygen instead of air, different gas cleaning technologies ${ }^{11}$ and a comparison of scenarios for variations in the fuel mix. Regarding the fuel mix it was also advised to include $\mathrm{CO}_{2}$ emissions emitted during growing, processing and transport of biomass in the assessment. $\mathrm{CO}_{2}$ capture and processing was also considered an important alternative to be assessed, though the scope and level of detail of assessing this alternative were not mentioned.

Electrabel plans to build a coal/biomass fired supercritical power plant in the Rotterdam area. Design alternatives proposed in the inception note (Electrabel, 2005) followed by the AoG (Commissie MER, 2006d)

\footnotetext{
${ }^{11}$ Gas cleaning technologies comprises both pre-combustion cleaning of the syngas (removal of $\mathrm{H}_{2} \mathrm{~S}$ and $\mathrm{CO}_{2}$ ), being the product of the gasification process, and post combustion flue gas cleaning (such as removal of fine particulate matter, $\mathrm{NO}_{x}$ through Selective Catalytic Reduction and $\mathrm{SO}_{2}$ with Flue Gas Desulphurization).
} 
Table 4

Alternatives assessed in analogue EIA procedures in the Netherlands

\begin{tabular}{|c|c|c|}
\hline Power plant & Transport by pipeline & Storage in geological formations \\
\hline $\begin{array}{l}\text { - Location alternative } \\
\text { - IGCC biomass and coal fired combined with NGCC } \\
\text { - USC PC boiler fired with coal and biomass } \\
\text { - CFB coal and biomass fired } \\
\text { - NGCC } \\
\text { - Proposed alternative with higher efficiency } \\
\text { - Alternatives including the use of steam and/or heat for } \\
\text { respectively industrial processes and district heating. } \\
\text { - } \mathrm{CO}_{2} \text { capture as additional mitigation measure } \\
\text { - Particulate matter reduction } \\
\text { - Alternatives for } \mathrm{SO}_{x} \text { removal } \\
\text { - Alternatives for } \mathrm{NO}_{x} \text { removal } \\
\text { - Alternative Cooling concepts } \\
\text { - Waste water treatment } \\
\text { - Noise and light emission mitigating options } \\
\text { - Design variants for the main building } \\
\text { - Reduction of bio fouling in cooling water section } \\
\text { - Partial load versus full load operation } \\
\text { - Minimisation of cooling water debit }\end{array}$ & $\begin{array}{l}\text { - Other transport media } \\
\text { - Pipeline routes } \\
\text { - Compressor location } \\
\text { - Compressor design } \\
\text { - Pipeline construction method } \\
\text { - Burial of pipeline } \\
\text { - Spatial and technical } \\
\text { alternatives for infrastructure } \\
\text { crossings } \\
\text { - Timing of construction } \\
\text { - Decommissioning alternatives } \\
\text { - Isolation alternatives } \\
\text { - Offshore pipeline stabilisation } \\
\text { techniques } \\
\text { - Safety alternatives } \\
\text { - Pre-commissioning (pipeline } \\
\text { test water disposal) }\end{array}$ & $\begin{array}{l}\text { - Alternatives to storage in geological formations } \\
\text { - Location alternatives } \\
\text { - Reservoir alternatives } \\
\text { - Compressor design (gas fired or by electricity) } \\
\text { - Alternatives to injection of production waste water } \\
\text { - Waste water injection installations (route of piping, } \\
\text { location and alternatives to water injection) } \\
\text { - Operational pressure in caverns } \\
\text { - Noise mitigation drilling and compression } \\
\text { - Height of gas blow off funnel } \\
\text { - Well drilling methods } \\
\text { - Frequency of drilling activities and number } \\
\text { of wells } \\
\text { - Processing of drilling grit } \\
\text { - Gas treatment alternatives } \\
\text { - Safety concept alternatives } \\
\text { - Height of buildings } \\
\text { - Alternative routes for piping } \\
\text { - Steam injection and oil production installation } \\
\text { (location, construction piping and pumping design) } \\
\text { - Size and number of production locations } \\
\text { - Timing of construction } \\
\text { - Timing of flaring and blow off }\end{array}$ \\
\hline
\end{tabular}

Note: alternatives in italics indicate that a selection for an alternative is discussed using, among others, environmental arguments although a comparison of alternatives is not included in the assessment.

comprises four design alternatives for the combustion concept: a pulverized coal boiler, a circulating fluidized bed boiler and gasification with the use of air or oxygen. Additional, several flue gas cleaning technologies, cooling techniques and various scenarios for variations in the fuel mix will be discussed in the EIS. The AoG also included a capture ready (post-combustion technology) design alternative. Another AoG added that also the implications of a capture ready design on the set-up of the power plant should be discussed (Commissie MER, 2006c). The NCEIA also recommended that attention should be paid to the transport and storage of the captured $\mathrm{CO}_{2}$ (Commissie MER, 2006d; Electrabel, 2005).

A study group (Jepma et al., 2006), which advises the Ministry of Economic Affairs (EZ) and Housing, Spatial Planning and the Environment (VROM), stated that it would be beneficial, if at the European level regulations would come into place which would obligate new power plants to be built capture ready. The implications of such a regulation for the EIA procedure would be that carbon capture is to be an obligated alternative to be assessed in the EIA procedure.

The implications of a capture ready design on the selection of a location for a power plant are discussed by Gibbins et al. (2006). They argue that the feasibility study for and selection of a suitable location for such a plant should consider issues related to the transport and storage of $\mathrm{CO}_{2}$. For instance, a credible storage location and transport method should be identified for a capture ready power plant. Other economical issues are due to the proximity of storage locations or other $\mathrm{CO}_{2}$ sources. They should be addressed to reduce $\mathrm{CO}_{2}$ transport cost by sharing and minimising the infrastructure needed. Also, health and safety issues related to capture (e.g. amine and $\mathrm{CO}_{2}$ handling) and transport of $\mathrm{CO}_{2}$ should be addressed.

Severable initiators (NUON, ENECO, Electrabel and RWE) are considering multiple location alternatives for their new power plants and consequently started parallel EIA procedures for these locations. The AoG's for the projects initiated by NUON, ENECO and Electrabel stipulate the need for argumentation, based on environmental grounds, in the EIA procedure on the location of choice, though comparison of location alternatives was not requested. For unknown reasons, such a stipulation was not included in the AoG's for the projects initiated by RWE (Commissie MER, 2005b, 2005c, 2006e, 2006f, 2006g).

Regarding the procedures initiated by ENECO, an environmental NGO (Greenpeace) requested that energy 
saving measures as alternative to the project should also be included in the scope. The NCEIA considered energy saving measures not related to the activity to be beyond the scope of the EIA, as the procedure is intended to obtain an environmental permit for a power plant in which such provisions can not be included (Commissie MER, 2005a,b).

\subsubsection{Scoping in EIA for transport by pipeline in the Netherlands}

The scope of the assessment proposed in the AoG for a natural gas transport pipeline between Grijpskerk and Wieringermeer in the Netherlands includes alternatives for the route, construction techniques, timing of construction and leakage mitigating measures (Commissie MER, 2005a).

Another inception note/EIA report ${ }^{12}$ for a natural gas pipeline includes location alternatives for a compressor station, route alternatives, construction methods for the pipeline and crossings with other infrastructure (Arcadis, 2006). Interesting in this case is the advice of the NCEIA which stated that when describing the need for developing a pipeline it should be argued why other alternatives, such as transport by LNG tankers, are excluded on forehand (Commissie MER, 2006b).

The guidelines for an EIA for an offshore natural gas pipeline connecting the Netherlands and England adds alternatives for decommissioning the pipeline to the list of alternatives mentioned in the cases above (Commissie MER, 2003).

Additionally, design alternatives which may be of particular interest for $\mathrm{CO}_{2}$ transport by pipeline that can be considered in an EIA are (Barrie et al., 2004; Hooper et al., 2005; Kruse and Tekeila, 1996; National Energy Board, 1998; Turner et al., 2006; Vendrig et al., 2003):

- Soil coverage of pipeline: increasing the depth of the pipeline is a measure to reduce the probability of $\mathrm{CO}_{2}$ escape due to damage caused by digging activities later.

- Phase of $\mathrm{CO}_{2}$ during transport, which can be gaseous, liquid or supercritical. The phase depends on temperature and pressure of the $\mathrm{CO}_{2}$ in the pipeline.

- Pipeline material, wall thickness, protection and isolation to reduce failure rates, avoid corrosion and heat transfer between pipeline and its environment.

- Pipeline diameter: over-sizing the pipeline may prove to be a more flexible option as more $\mathrm{CO}_{2}$ sources can be added in the future.

\footnotetext{
${ }^{12}$ Inception note and preliminary EIS are integrated into one document for this project.
}

\subsubsection{Scoping in EIA for $\mathrm{CO}_{2}$ storage in geological formations in the Netherlands}

A planned EOR project at Schoonebeek (province of Drenthe) based on the injection of steam in an oil field that has been out of production since 1996 may be an interesting analogue to $\mathrm{CO}_{2}$ storage in geological formations. The scope of the EIA for this project includes: a Combined Heat and Power plant for steam production, water treatment plant for purification, steam injection and oil production installation, oil treatment installation and waste water injection installations. The AoG stipulates that the comparison of alternatives should include location alternatives for the activities and their relating infrastructure (Commissie MER, 2004).

Another example is the EIA procedure for the underground gas storage (UGS) in an empty gas field at Langelo in the Province of Drenthe, the Netherlands. For this project the storage location at Langelo was the subject of the assessment and denominated the location of preference by the initiators (NAM and Gasunie). The procedure was significantly delayed ${ }^{13}$ due to the demand for more information on the necessity of the UGS facility for the Dutch natural gas supply. Furthermore, before the regional spatial plan could be revised to implement and formally allow the UGS activity, the location at Langelo had to be proven to be the most suitable one and thus alternatives had to be assessed on their suitability (ECN, 1994; NAM/ GASUNIE, 1991). This led to a broadening of the scope of the assessment. Apart from considering other storage locations also strategic alternatives were assessed by investigating means to neutralize the need for underground gas storage.

The UGS project at Zuidwending encompasses salt production from an underground salt layer that would create caverns in which, in this case, natural gas can be stored. The alternatives proposed by the initiator were primarily design and operation alternatives (KEMA, 2003). The NCEIA advised to assess alternatives to the locations of the caverns within the selected salt layer, the depth of the caverns, the size and number of caverns, as well as alternative drilling activities and routes for pipelines.

\footnotetext{
13 The EIA procedure started in June 1991 and the EIA report was finished at the end of 1992. In April 1993 the application for the revision of the local zoning plan was rejected. In December 1994 the Minister of VROM issued a designation order to revise the regional spatial plan of the province of Drenthe. The construction of the facility eventually started in 1995 and was operational in 1997.
} 
The alternatives to be assessed in two EIA's for the production of natural gas at locations Westbeemster, Middelie en Rustenburg in the Netherlands and near the Waddenzee were the design options for the harmonization of proposed locations into the landscape, various road transport routes (natural gas pipeline not included), construction alternatives (techniques and timing) and route of the natural gas pipeline (NAM, 2005a,b).

\subsection{CCS activities: one facility or various installations}

In the Netherlands, it is set in regulations that, if related activities can be foreseen they are considered to be part of the project and consequently they must be included in the EIA. A question is therefore: are the power plant with capture technology, transport and underground storage inherently linked to each other and can they be considered one facility?

The definition of a facility according to article 1.1:4 of the Environmental Management Act reads: 'One facility is considered to be the collection of accompanying installations that have a technical, organizational or functional bound and are in each others direct vicinity, belonging to the same company or institution' (Wet milieubeheer, 1979). It thus includes three provisions of which one is that the activities should be in each others direct vicinity to be characterized as one facility. In legal precedents direct vicinity is explained as 'less than $1000 \mathrm{~m}$ '.

In a precedent the Dutch Council of State ruled that the pipelines between two construction sites are considered to be part of that facility (ABRS, 2003). From this perspective the pipeline between a power plant and a storage installation should considered to be part of those installations, being it not that in this project the second criterion of proximity $(<1000 \mathrm{~m})$ was also fulfilled (Cozijnsen, 2005). One can argue that if the distance between the capture plant and $\mathrm{CO}_{2}$ injection installation is more than $1 \mathrm{~km}$, this criterion is not met and the activities are consequently not part of one facility. Consequently, the integration of associated CCS activities into one EIA procedure is probably not obligated. In that case the choice is up to the initiators of the CCS project. The integration into one procedure may have the benefit that decision making process and the assessment of impacts is better coordinated (Backes, 2006).

Furthermore, Aspelund and Jordal (2006) state that a power process with $\mathrm{CO}_{2}$ capture should preferably be designed in conjunction with transport. A similar pronouncement is done by Gibbins et al. (2006). Design and operating alternatives for one activity may thus affect possible alternatives and choices for design and operation of the other activities in the CCS chain. The possible environmental impacts ensuing from these other activities and their alternatives in the chain then also should not be ignored. This issue was also identified in the IPCC special report on CCS and it is stated that impurities in the $\mathrm{CO}_{2}$ stream from the power plant may result in environmental impacts at the storage site (IPCC, 2005; p.141).

\section{Discussion}

Based on the sections above we have constructed a conceptual taxonomy for the scope of both EIA and SEA procedures for CCS in the Netherlands. EIA and SEA are intended to be complementary tools for tiered levels of decision making (see also (Partidario, 2000)) Consequently, a certain degree of overlap in the scope of both procedures is unavoidable. Moreover, regulation provides the possibility to integrate both procedures into one comprehensive report addressing the various levels. To emphasize this, the terms 'vertical and horizontal expansion of the scope' are introduced. Horizontal expansion depicts the integration of linked activities, including alternatives, into one procedure. The vertical expansion conceptualizes the integration of various levels of decisions with matching scope and assessments into one procedure.

\subsection{Vertical expansion}

We have seen some examples in which the scope of the assessment was expanded vertically: The EIA's for power plants in which arguments for the location of choice were asked for. However, a detailed comparison of location alternatives for power plants with $\mathrm{CO}_{2}$ capture is more likely to be considered within the scope of an SEA to be performed for the new National Structure Plan for the Electricity Supply (SEV III). In the case of natural gas transport by pipeline also other transport media are to be assessed. For transport by pipelines, the replacement of the National Structure Plan for Pipelines provides an opportunity to compare various routes for trunk $\mathrm{CO}_{2}$ pipelines on their possible environmental impacts in an SEA. Such main $\mathrm{CO}_{2}$ routes would come into perspective if a large scale shared $\mathrm{CO}_{2}$ infrastructure is envisioned, contrary to dedicated source-to-sink pipelines. For storage projects in the deep underground we have seen vertical expansion of the scope of the assessment by the request for evaluating various location alternatives and, on a higher level, strategic alternatives for fulfilling the goal of the proposed activity. The Gorgon project in Australia 
and the UGS project at Langelo/Norg are good examples.

Determining which alternatives to include in the scope of the SEA for underground storage of $\mathrm{CO}_{2}$ depends on the definition of the goal of the plan for which the SEA is obligated. The NCEIA already suggested that a tiered approach should be applied on SEA's in the future. This means concretely that on the first level a broad set of strategic alternatives is selected for the fulfillment of the proposed goal of the plan. Then on lower levels more concrete alternatives should be assessed on a more detailed level. For CCS and specifically for $\mathrm{CO}_{2}$ storage this could mean the following.

If the goal of the policy plan is to reduce anthropogenic $\mathrm{CO}_{2}$ emissions from the energy sector, possible alternatives which have to be assessed in the SEA are other strategies to reduce $\mathrm{CO}_{2}$ emissions, such as more efficient use of energy and the deployment of renewable energy technologies (e.g. wind, solar and biomass energy) or nuclear energy.

If the goal of the plan is to store $\mathrm{CO}_{2}$ to prevent its emission into the atmosphere, then possible alternatives are: geological storage (offshore and onshore), ocean storage and mineral carbonation (IPCC, 2005).

Comparisons of various geological storage media provide yet another level of detail for the selection of alternatives. In that case, possibilities for storing $\mathrm{CO}_{2}$ in unminable coal seams, (nearly) depleted gas and oil fields and deep saline aquifers may be assessed and compared.

Other alternatives also come into perspective when addressing a strategic vision of the government on the use of the underground, such as: geothermal heat production, storage of cold and heat, underground (natural) gas storage, storage of waste and injection of produced water from the oil and gas industry. These alternatives can pose conflicts between different options for using the underground as well as spatial needs at the surface. Regarding competition in the underground, Croezen et al. (2004) argue that a decision on the preferred alternative for the use of an empty gas field should be made on a regional or national level and not on the project level. From the governments perspective, a framework should be constructed to evaluate the various functions of the underground (VROM, 2004a) and implement this in spatial plans. This implicates that various alternatives for the use of the underground and the spatial activities involved should be assessed in the framework of an SEA procedure on the regional and national level.

Spatial planning and the selection of storage media are highly related as storage media are not equally distributed over the Netherlands. Coal seams which are potentially suitable for ECBM production and $\mathrm{CO}_{2}$ storage are located in four areas in the east, southeast and southwest of the country ${ }^{14}$ (Hamelinck et al., 2001). Onshore gas and oil fields are located in the west and northeast and offshore fields are situated north-west from the Netherlands. Aquifers are distributed more homogeneously over the country (Damen et al., 2006). The selection of a certain storage media thus defines the area of possible locations for $\mathrm{CO}_{2}$ storage. Vice versa, the appointment of an area suitable for $\mathrm{CO}_{2}$ storage projects in spatial planning procedures implicitly involves a selection of storage media.

In Decision 2003/33/EC of the European Council criteria are formulated for the acceptance of waste in the underground in pursuance of Directive 1999/31/EC. The Directive is enforced in the NWMP. Although the Decision is not (yet) implemented in national legislation or the NWMP, it may provide criteria for the underground storage of $\mathrm{CO}_{2}$. In the EIA for the EOR project at Schoonebeek the criteria formulated in the Decision are already applied (Haskoning Nederland B.V., 2006; NAM, 2004). In the Decision it is stated that for a storage site a site specific risk assessments must be performed. An integral performance assessment of the site must also include the geological assessment of alternative site locations (EC, 2003). This implicates that when a storage site is suggested this Decision requires that alternatives to this site are assessed on their suitability for storage as well.

Comparing the various $\mathrm{CO}_{2}$ storage media on their possible environmental impacts and subsequently comparing alternative locations for $\mathrm{CO}_{2}$ storage will demand extensive research (site characterization) and financial efforts. An integral performance assessment of a storage reservoir will be less extensive for gas and oil fields as their characteristics, needed to perform such an assessment, are better known compared to the mentioned coal seams and aquifers.

If plans (as mentioned in Table 3) provide a substantial framework for the appointment of possible locations for EIA obligated storage sites they are SEA obligated. The comparison of storage media and alternative locations are thus typical strategic assessments which according to the criteria mentioned for the SEA procedure should preferably be included in an SEA and not in an EIA for a project.

For CCS in the Netherlands the discussion above also implicates that when a $\mathrm{CO}_{2}$ storage project is initiated it is not just hypothetical that an EIA procedure will

\footnotetext{
${ }^{14}$ Areas are the Peel, Zuid Limburg, Achterhoek and Zeeland.
} 
encounter the vertical expansion of the scope and delay discussed earlier for the UGS facility at Langelo/Norg, if other storage options and locations are not assessed earlier in an SEA for decisions on the higher strategic (plan) level.

It is therefore recommended to perform an SEA for $\mathrm{CO}_{2}$ storage locations before an EIA is started for an actual project. This SEA is ideally to be triggered by the appointment of $\mathrm{CO}_{2}$ storage areas and reservoirs in a national spatial policy plan (structure vision) for the use of the underground, which has not been formulated. The follow up of the national waste management plan is also of interest in this respect as this SEA obligated plan is expected to include policy on the legal status of $\mathrm{CO}_{2}$ and criteria for underground storage.

\subsection{Horizontal expansion}

Next to the vertical expansion of the scope attributed to the Gorgon project, this project also exemplifies a horizontal integration (see Fig. 1) of various activities into one EIA procedure. Also, horizontal integration is seen in the EOR project at Schoonebeek (Netherlands), the ZeroGen project in Australia and in the ECBM field test in USA. The environmental assessment of the Souris $\mathrm{CO}_{2}$ pipeline for the Weyburn project (Canada) indicates a contrasting clear horizontal demarcation of the project. In that case the pipeline and storage are considered separate projects.

Another example for the horizontal expansion of the scope in one of the EIA's is, as it was suggested by the NCEIA (see Section 6.3.1), to include and assess the $\mathrm{CO}_{2}$ emissions upstream of the combustion process. It is not unlikely that also downstream emissions due to transport and storage should be taken into account as well when comparing alternatives (see also Section 6.4).

The question remains if in the assessment of environmental impacts of the capture (ready) alternative the directly related transport and storage/usage is consequently also included in the scope of that particular procedure. Formally, the three activities are separated (see Section 6.4). However, it cannot be ignored that $\mathrm{CO}_{2}$ capture, transport and storage are highly, if not inherently, linked activities and that environmental impacts in one part of the CCS chain may be affected by choices on geographical situation, design and operation in other parts. Therefore, in the scoping phase of both procedures special attention should be paid to the horizontal integration of CCS activities and their alternatives into one procedure.

Concisely, there are two linking characteristics: the geographical situation and the $\mathrm{CO}_{2}$ product stream. This requires matching of source and sink based on geography and capacity, resulting in the determination of an optimal $\mathrm{CO}_{2}$ infrastructure. As proposed earlier the vision of a CCS infrastructure should be implemented in national spatial policy. The three policy plans suitable for this are also mentioned. A problem, however, is that no national spatial plan explicitly acknowledges the linkages between $\mathrm{CO}_{2}$ capture, transport and storage and that these policy plans may incorporate merely the individual elements of the CCS chain. Enthoven (2004) already mentioned the option to integrate the structure visions for pipelines and electricity supply. A strategic vision on the use of the deep underground would be a valuable addition to such an integrated structure vision. It is therefore recommended to formulate one structure vision for CCS. This is horizontal integration on the strategic level.

The second characteristic, the $\mathrm{CO}_{2}$ product stream, can be divided into the quantity, and the chemical and thermodynamic properties of the stream. These properties are determined by design and operation concepts in the $\mathrm{CO}_{2}$ capture plant and compressor facility for transport. Limitations of these properties may be set due to the design of the pipeline and storage installation, and characteristics of the reservoir.

For the first EIA's this means that alternatives that are taken into consideration for one element of the chain and that affect the quantity and quality of the $\mathrm{CO}_{2}$ stream or set requirements thereof, should be communicated to the initiators of the other elements of the CCS chain. This also requires that competent authorities have an overview of the various projects. Another possible problem with the horizontal linking of EIA's is timing, as the procedures and realization of the three elements have different timelines ${ }^{15}$. To overcome this, there is the option to apply the earlier mentioned state project procedure on CCS projects. When applied, decision making in the various spatial planning and environmental procedures of the individual elements can be coordinated by one body, in this case, the Bureau for Energy projects. This will ensure that decision making procedures run parallel. In this way coordination of competent authorities, and moments of third party participation (NGO's, public, NCEIA and formal advisors) and for appeal are centralized and synchronized. This is horizontal integration on the project level.

\footnotetext{
${ }^{15}$ For a (coal) power plant with $\mathrm{CO}_{2}$ capture we estimate that the EIA plus additional procedures and construction is expected to comprise a period of 6 years, for a pipeline 4-5 years and for a storage installation $4-5$ years.
} 
Capture

Transport

Storage

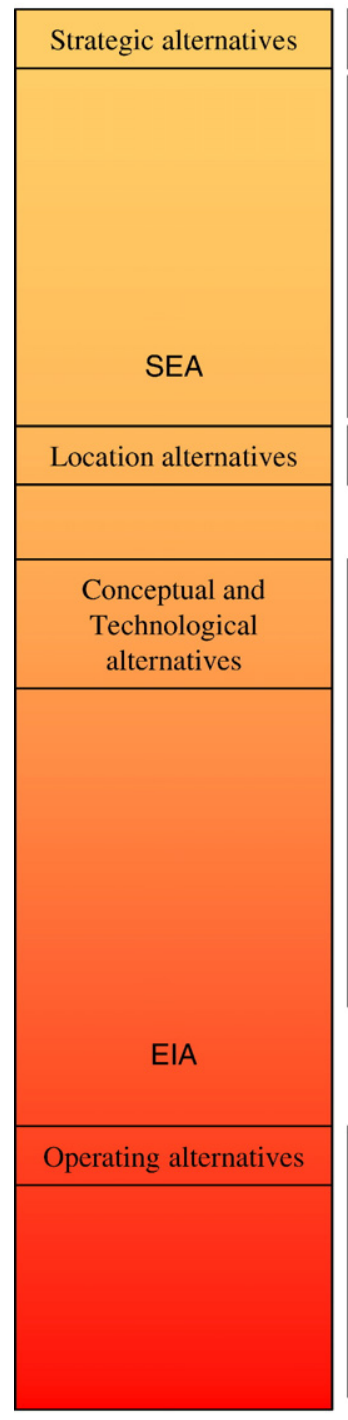

\begin{tabular}{|l|}
\hline \multicolumn{1}{|c|}{ Alternatives for reductio } \\
\hline $\begin{array}{l}\text { Scenario's : } \\
\text {-Future electricity } \\
\text { demand } \\
\text {-Centralized vs. } \\
\text { decentralized generation } \\
\text {-Conversion technologies } \\
\text { Dutch installed base } \\
\text {-Emission reduction } \\
\text { technologies }\end{array}$ \\
\hline $\begin{array}{l}\text { Power plant site selection } \\
\text { - Minimisation of cooling } \\
\text { water debit } \\
\text { - Partial load vs. full load } \\
\text { - Fuel mix scenarios } \\
\text { - CO, Capture rate } \\
\text { - Aesthetic design of } \\
\text { buildings } \\
\text { - Use of steam and/or } \\
\text { heat } \\
\text { - Oxygen or air firing } \\
\text { concept } \\
\text { - Cooling concept } \\
\text { - (Flue) gas cleaning } \\
\text { technologies } \\
\text { - capture }\end{array}$ \\
\hline
\end{tabular}

Other transport media

(ship ,train and truck)

Possible routes for $\mathrm{CO}_{2}$ trunk lines

-Site specific route

variants

-Construction techniques

-Leakage mitigating

measures

- Pipeline diameter,

- Pipeline material, wall

thickness, protection and

isolation

-Soil coverage

(underground vs. above

ground)

- Crossings with other

infrastructure

- Compressor design

- Phase of $\mathrm{CO}_{2}$ (gaseous,

liquid or supercritical)

- Stream composition

- Timing of construction
Other options for $\mathrm{CO}_{2}$ storage (ocean, mineral carbonation)

Competition in the underground (e.g. UGS)

Other geological storage options for $\mathrm{CO}_{2}$

Selection of site for geological storage

-Exact location alternatives for the installation

-Route of relating infrastructure

- Construction techniques

-Drilling techniques and number of wells

-Drilling waste treatment options

- Noise mitigation options

-Blow out prevention

- Compressor/pump design

- Injection rate

- Injection pressure

- Reservoir pressure

- Timing of construction

\section{$\leftarrow$ Horizontal expansion of the scope}

Fig. 1. Scope of EIA and SEA procedures for CCS policy, plans, programmes and projects.

Finally, additions of CCS elements to an already existing $\mathrm{CO}_{2}$ infrastructure are of less complexity, regarding the EIA procedure, as the other CCS elements are already realized and with it specific requirements for the quantity and quality of $\mathrm{CO}_{2}$ stream are set.

\section{Conclusions}

Currently the legal status of $\mathrm{CO}_{2}$ is unclear. This makes it difficult to apply current EIA/SEA regulation and thresholds on CCS activities. The thresholds can be interpreted ambiguously for $\mathrm{CO}_{2}$ as no direct reference to $\mathrm{CO}_{2}$ is included in the EIA decree. Nevertheless, following current regulations, commercial scale $\mathrm{CO}_{2}$ capture and storage activities are by all appearances obligated to perform an EIA. Notwithstanding that clarity is needed on the EIA (judgement) obligation of the addition of a $\mathrm{CO}_{2}$ capture installation and for $\mathrm{CO}_{2}$ storage activities for which an EIA threshold is lacking and current thresholds do not apply. Transport of $\mathrm{CO}_{2}$ by pipeline is not likely to be EIA obligated, when assuming a direct dedicated connection between the source and the sink. Transport of $\mathrm{CO}_{2}$ by pipeline is only EIA (judgement) obligated when it encompasses large transport capacities $(>24 \mathrm{Mt} /$ year $)$ or is projected through sensitive areas. Short term actions to achieve 
clarity in this matter are recommended. These actions encompasses a formal statement by the government on the legal status of $\mathrm{CO}_{2}$ (dangerous waste, nondangerous waste or asset) and how the EIA thresholds must be applied on CCS activities. This may require alteration or addition of thresholds in the regulations. In the case where EIA (judgement) obligation is uncertain it is recommended that project initiators start a voluntary EIA to avoid delay later in the decision making process.

Governmental plans which contain decisions on the appointment of possible locations or routes, or the consideration of alternative locations or routes for CCS activities are expected to be SEA obligated. SEA-like procedures have been used in spatial planning decisions to determine possible locations for projects (i.e. designation of possible locations for power plants and routes of natural gas pipelines). This approach should be applied on the appointment of possible $\mathrm{CO}_{2}$ storage locations as well. This can be achieved by formulating one structure vision for a CCS infrastructure in which source and sink locations and transport routes for $\mathrm{CO}_{2}$ are identified at an early stage and included in strategic decision making for national and regional spatial planning. This will initiate an SEA for CCS activities preferably including the assessment of higher strategic alternatives such as renewables and energy saving measures. Early action may also avoid conflict with other surface and subsurface spatial functions (e.g. gas storage, earth heat, oil/gas extraction) and incorporate possible environmental impacts as criteria in strategic decision making. Performing an SEA for CCS first will have the benefit that the scope of following EIA procedures on the project level will not be subjected to vertical expansion and with it possibly ease the planning and implementation of future (commercial) CCS projects.

Although the three distinctive steps of $\mathrm{CCS}\left(\mathrm{CO}_{2}\right.$ capture, transport and storage) are formally separated activities, we recommend combining the separate EIA procedures for CCS activities into one procedure or at least to provide close linkage between them. This can be achieved by applying the state project procedure on CCS projects. This provides overall insights into environmental burdens of the entire CCS chain and will streamline the various decision making procedures. If in practice the EIA procedure would be performed for the activities separately, then the EIA procedure should deal explicitly with the links with the other activities and their alternatives. This includes the assessment of environmental impacts of the full CCS chain induced by alternatives in the separately proposed CCS activity.

These issues should be carefully considered by regulators, competent authorities and project initiators in an early stage to avoid delaying legal procedures.
It is not the goal of this article to determine what the scope for both procedures for CCS projects should be. This should be the outcome of a process where all the relevant actors are consulted.

Early involvement of public, interested parties and the NCEIA in the scoping phase of the procedures is desired. This may increase public awareness and societal acceptance, help focus the assessment and reduce the possibility of delay later in the decision making process.

The findings presented above form the starting point of future work to provide more detailed insights into the environmental impacts of CCS activities and the methodologies used in EIA and SEA procedures to assess them.

\section{Acknowledgements}

We would like to acknowledge the contributions of Chris Backes (University of Utrecht), Bert Wilbrink (Ministry of Economic Affairs), Stefan Morel and Geert Draaijers (NCEIA) to this article. This research is part of the CATO programme, the Dutch national research programme on Carbon dioxide Capture and Storage. CATO is financially supported by the Dutch Ministry of Economic Affairs (EZ) and the consortium partners, http://www.co2-cato.nl. The views expressed in this article are not necessarily those of the research programme and funding partners.

\section{References}

ABRS. Dossier nr. 200204674/2, Afdeling Bestuursrechtspraak van de Raad van State. 20-august-2003; 2003 (Dutch).

ABRS. Dossier nr. 200205532/1, Afdeling Bestuursrechtspraak van de Raad van State. 2-june-2004; 2004 (Dutch).

Afval Overleg Orgaan. Milieueffectrapport Landelijk Afvalbeheersplan 2002-2012. Utrecht: Afval Overleg Orgaan; 2002a (Dutch).

Afval Overleg Orgaan. Milieueffectrapport Landelijk Afvalbeheersplan- Achtergronddocument A2 LCA; methodiek en uitwerking in het LAP; 2002b (Dutch).

Arcadis. Startnotitie aardgasleiding Zuid-Beveland, Delta N.V.; 2006 (Dutch).

Aspelund A, Jordal K. A study of the interface between $\mathrm{CO}_{2}$ capture and transport. Proc. of Greenhouse Gas Control Technologies, vol. 8. Norway: Trondheim; 2006.

Backes CW. Personal communication on Dutch environmental law. August 2006; 2006. Utrecht.

Barrie J, Brown K, Hatcher PR, Schellhase HU. Carbon dioxide pipelines: a preliminary review of design and risk. Proc. of Greenhouse Gas Control Technologies, vol. 7. Canada: Vancouver; 2004.

Bolhuis AV, Burkunk R, Creemer M, Frijling H, Veld JHIT, Koole E, et al. Provinciaal Omgevingsplan, Province of Groningen; 2000 (Dutch).

Buyze KMH, Zeverijn AP, Gendt SPCV, Alderliesten MA, Geuns LCV, Tönjes C, Perlot WG, Waal WWVD, Drenth D, Klaversteijn BB. CEPP / ZEPP Haalbaarheidsonderzoek naar klimaatneutrale 
elektriciteitsopwekking in Nederland, NIBConsult B.V., NV ONS Energie, Van de Waal Mijnbouwkundig Ingenieursbureau B.V. (WMI). Clingendael International Energie Programme (CIEP); 2004 (Dutch).

CDA, PvdA, ChristenUnie. Coalitieakkoord tussen de Tweede Kamerfracties van CDA, PvdA en ChristenUnie. 7 February 2007; 2007 (Dutch)

Chevron Australia. Chapter 3: Development Alternatives, Gorgon Joint Venturers; 2005a.

Chevron Australia. Chapter 13: Greenhouse gas emissions — risks and management, Gorgon joint venturers; $2005 \mathrm{~b}$.

Commissie MER. Advies voor richtlijnen voor het milieueffectrapport Gaspijpleiding Balgzand-Bacton (UK); 2003 (Dutch).

Commissie MER. Herontwikkeling van het olieveld Schoonebeek Advies voor richtlijnen voor het milieueffectrapport; 2004 (Dutch).

Commissie MER. Aanleg Aardgastransportleiding Grijpskerk-Wieringermeer - Advies voor richtlijnen voor het milieueffectrapport; 2005a (Dutch).

Commissie MER. Elektriciteitscentrale Eemshaven ENECO — Advies voor richtlijnen voor het milieueffectrapport; 2005b (Dutch).

Commissie MER. Elektriciteitscentrale Europoort ENECO — Advies voor richtlijnen voor het milieueffectrapport; 2005c (Dutch).

Commissie MER. Reactie op Kamerstukken 29811, nr. 2 en 29383, nr. 25; 2005d (Dutch).

Commissie MER. Strategische Milieubeoordeling Zuiderzeelijn Advies over de reikwijdte en het detailniveau van de Strategische Milieubeoordeling. 25 november 2005; 2005e (Dutch).

Commissie MER. Aardgasgestookte STEGcentrale InterGen in Rijnmond te Pernis - Advies voor richtlijnen voor het milieueffectrapport; 2006a (Dutch).

Commissie MER. Aardgasleiding Zuid-Beveland - Advies voor richtlijnen voor het milieueffectrapport; Commissie MER; 2006b (Dutch).

Commissie MER. Bouw van een 1600-2200 MWe kolengestookte elektriciteitscentrale in de Eemshaven door RWE Power AG Advies voor richtlijnen voor het milieueffectrapport; 2006c (Dutch).

Commissie MER. Kolen-en biomassacentrale Electrabel op de Maasvlakte te Rotterdam - Advies voor richtlijnen voor het milieueffectrapport; 2006d. Zwolle (Dutch).

Commissie MER. Multi-fuel centrale van Nuon in de Eemshaven Advies voor richtlijnen voor het milieueffectrapport; 2006e (Dutch).

Commissie MER. Multi-fuel centrale van Nuon in het Sloegebied Advies voor richtlijnen voor het milieueffectrapport; $2006 \mathrm{f}$ (Dutch).

Commissie MER. Multi-fuel centrale van Nuon op de Maasvlakte Advies voor richtlijnen voor het milieueffectrapport; 2006g (Dutch).

Commissie MER. STEG-eenheid Moerdijk — Advies voor richtlijnen voor het milieueffectrapport; 2006h (Dutch).

Commissie MER. Structuurvisie Zuiderzeelijn Toetsingsadvies over de toegevoegde documenten Strategische Milieubeoordeling. 10 October 2006; 2006i (Dutch).

Consol Energy inc. Draft Environmental Assessment (EA) - Enhanced Coalbed Methane Production and Sequestration of $\mathrm{CO}_{2}$ in Unmineable Coal Seams. Marshall County, West Virginia, U.S. Department of Energy, National Energy Technology Laboratory; 2002.

Cozijnsen CJH. Het Recht op $\mathrm{CO}_{2}$-credits van Zero Emission Power Plants; 2005 (Dutch).

Croezen HJ, Sevenster MN, Kampman BE, Swigchem JV. Met water de diepte in-Afwegingsmethodiek voor vergunningen rond diepe injectie van waterstromen van olie-en gaswinning. Delft: CE; 2004 (Dutch).
CRUST Legal Task Force. Legal aspects of underground $\mathrm{CO}_{2}$ buffer storage. Den Haag; 2001

D'Hoore D. Opslag van $\mathrm{CO}_{2}$ in een leeg offshore gasveld- Fase 2: Demonstratie op de K12-B [presentation on 18-05-2005]. Gaz de France; 2005.

Damen K, Faaij A, Turkenburg AW. Developing strategies for largescale implementation of $\mathrm{CO}_{2}$ capture and storage: a case study for the Netherlands. proc. of Greenhouse Gas Control Technologies, vol. 8. Trondheim: Elsevier; 2006.

EC. The Council Directive 79/409/EEC of 2 April 1979 on the conservation of wild birds (the Birds Directive), European Council ; 1979.

EC. The Council Directive 92/43/EEC of 21 May 1992 on the conservation of natural habitats and of wild fauna and flora (the Habitats Directive), European Council; 1992.

EC. Council Decission (2003/33/EC) of 19 December 2002 establishing criteria and procedures for the acceptance of waste at landfills pursuant to Article 16 of and Annex II to Directive 1999/31/EC, European Council. 16-1-2003; 2003.

ECN. Gasopslag, in: Energie Verslag Nederland 1994. Petten: ECN; 1994 (Dutch).

Electrabel. Startnotitie Milieu Effect Rapportage: Nieuwe kolen/ biomassacentrale Rotterdam. Zwolle: Electrabel; 2005 (Dutch).

Electrabel. Electrabel, overheid en milieubeweging bereiken akkoord over centrale Nijmegen, Electrabel E-ditie, 11 oktober 2006; 2006. https://mm.mailing-electrabel.nl/35/pages/website/newsitems.asp? $\mathrm{id}=373 \# 373$. (Dutch).

Enthoven MEE. Samen voor de buis - Advies over het dossier Buisleidingen. Den Haag: VROM, V\&W and EZ; 2004 (Dutch).

Eriksson S, Andersson A, Strand K. Using a strategic environmental assessment approach for assessing environmental impacts of $\mathrm{CO}_{2}$ capture, transport and storage alternatives. proc. of Greenhouse Gas Control Technologies, vol. 8. Trondheim: Elsevier; 2006.

EU. Amended Environmental Impact Assessment Directive 97/11/ EC: P. 0005; 1997.

EU. Strategic Environmental Assessment Directive 2001/42/EC; 2001.

European Commission. How successful are the Member States in implementing the EIA Directive- On the Application and Effectiveness of the EIA Directive (Directive 85/337/EEC as amended by directive 97/11/EC); 2002.

EZ, V\&W, VROM. Structuurschema Buisleidingen-deel a beleidsvoornemen. Staatsuitgeverij, Den Haag, Ministerie van Economische Zaken, Ministerie van Verkeer en Waterstaat and Ministerie van Volkshuisvesting en Ruimtelijke Ordening; 1982-1984 (Dutch).

EZ, VROM. Tweede Structuurschema Elektriciteitsvoorziening. Staatsuitgeverij, Den Haag, Ministerie van Economische Zaken and Ministerie van Volkshuisvesting en Ruimtelijke Ordening en Milieubeheer; 1994 (Dutch).

Finnveden G, Nilsson M, Johansson J, Persson A, Moberg A, Carlsson T. Strategic Environmental Assessment methodologies-applications within the energy sector. Environ Impact Asses Rev 2003;23(1):91.

Gedeputeerde Staten van Friesland. Ontwerp Streekplan Fryslân 2006Om de kwaliteit fan de romte; 2005 (Dutch).

Gibbins J, Irons R, Panesar R, Sekkapan S. Study on $\mathrm{CO}_{2}$ capture ready power plants - Working Draft December, Prepared for IEA Greenhouse Gas Research: Imperial College, E.ON UK PLC, Mitsui Babcock; 2006.

Hamelinck CN, Faaij APC, Ruijg GJ, Jansen D, Pagnier H, Bergen FV, et al. Potential for $\mathrm{CO}_{2}$ sequestration and Enhanced Coalbed Methane production in the Netherlands, vol. 51. Utrecht: NOVEM Netherlands Agency for Energy and the Environment; 2001. 
Haskoning Nederland BV. Milieueffectrapportage Herontwikkeling olieveld Schoonebeek. Assen: NAM; 2006 (Dutch).

Hooper B, Murray L, Gibson-Poole C. Latrobe Valley $\mathrm{CO}_{2}$ Storage Assessment, $\mathrm{CO}_{2}$ CRC; 2005.

IEA. Netherlands - Standard Review, in: Energy Policies of IEA Countries. International Energy Agency; 2006.

IPCC. In: Metz B, Davidson O, Coninck HCD, Loos M, Meyer LA, editors. IPCC Special Report on Carbon Dioxide Capture and Storage, vol. 442. Cambridge: Cambridge University Press; 2005.

Jepma C, Gigler J, Schreurs H, Aubert P, Cahen H, Groeningen MV, et al. Advies van de werkgroep Schoon Fossiel van het Platform Nieuw Gas aan de Task Force Energietransitie, Platform Nieuw Gas Werkgroep $\mathrm{CO}_{2}$-opslag/Schoon fossiel; 2006 (Dutch).

Jesse KD, Verschuuren JM. De meerwaarde van milieu-effectrapportage. Een onderzoek naar de meerwaarde van milieu-effectrapportage bij vergunningverlening ingevolge de Wet milieubeheer, vol. 24(4). Milieu \& recht; 1997. p. 82-7. (Dutch).

KEMA. Startnotitie Milieueffectrapportage- ondergronds aardgasbuffer Zuidwending, vol. 23. Arnhem: Kema; 2003. (Dutch).

KEMA. Startnotitie Bouw van een 1600-2200 MWe kolengestookte elektriciteitscentrale Eemshaven door RWE Power AG. Arnhem: RWE Power AG; 2006 (Dutch).

Klooster JPGN, Bergsma GC, Buck AD. Strategische Milieubeoordeling Zuiderzeelijn- De ruimtelijk-economische projecten in het Regiospecifieke Pakket. Delft: CE; 2006. september 2006.(Dutch).

Kongsjorden H, Karstad O, Torp TA. Saline aquifer storage of Carbon dioxide in the Sleipner project. Waste Manage 1998;17(5-6):303.

Kruse H, Tekeila M. Calculating the consequences of a pipeline rupture. Energy Convers Manag 1996;37(6-8):1013-8.

Mace MJ, Hendriks C, Coenraads R. Regulatory challenges to the implementation of carbon capture and geological storage within the European Union under EU and international law. Int J GHG Control 2007;1(2):253.

Mijnbouwwet (31 October 2002).

Milieuloket. Vereenvoudiging regels milieu-effectrapportage stuit op verzet, 27 jan 2005; 2005. http://www.milieuloket.nl/9292102/ modules/vg2chwjapyli?key=vgxhd7bruun6\&thema=vg93ohnt8mqn. (Dutch).

NAM. Startnotitie Milieu Effect Rapportage: herontwikkeling olieveld Schoonebeek; 2004 (Dutch).

NAM. Startnotitie Milieu Effect Rapportage: Aardgaswinning Waddenzeegebied vanaf locaties Moddergat, Lauwersoog en Vierhuizen; 2005a (Dutch).

NAM. Startnotitie Milieu Effect Rapportage: Winning en behandeling van aardgas uit de velden Westbeemster, Middelie en Rustenburg; 2005b (Dutch).

NAM/GASUNIE. Startnotitie Milieu-effectrapportage: Opslag van aardgas in het gasveld Norg; 1991 (Dutch).

National Energy Board. Reasons for Decision Souris Valley Pipeline Limited; 1998.

NETL. Environmental Assessment for Pilot Experiment for Geological Sequestration of Carbon Dioxide in Saline Aquifer Brine Formations, Frio Formation. Liberty County, Texas, U.S. Department of Energy, National Energy Technology Laboratory; 2003a.

NETL. PEIS Determination, U.S. Department of Energy, National Energy Technology Laboratory. 10/31/03; 2003b.

NETL. Carbon Sequestration Program Environmental Impact Statement- Public Scoping Report, U.S. Department of Energy, National Energy Technology Laboratory: 10/5/04; 2004a.

NETL. Notice of Intent to Prepare a PEIS, U.S. Department of Energy, National Energy Technology Laboratory. 4/21/04; 2004b.
NETL. Geosequestration field experiments, U.S. Department of Energy, Office of fossil energy, National Energy Technology Laboratory; 2005.

Niekerk F, Bos S, Sain MD, Lankveld J, Holsteijn CV. Strategische Milieubeoordeling Provinciaal Omgevingsplan Groningen II-Fase 3 Milieurapport, Royal Haskoning commisioned by Province of Groningen; 2005 (Dutch).

Novioconsult. Evaluatie m.e.r. 2003, VROM, OCW, LNV; 2003. (Dutch)

Partidario MR. Elements of an SEA framework - improving the added-value of SEA. Environ Impact Asses Rev 2000;20(6):647.

Province of Friesland. Milieurapport Streekplan Fryslân; 2005 (Dutch)

Province of Saskatchewan. Canadian Environment Assessment ActFive Year Review-appendix 1 case studies Saskatchewan-Souris Valley $\mathrm{CO}_{2}$ pipeline; 2000.

Provincie Drenthe. Meer onderzoek naar $\mathrm{CO}_{2}$-opslag in bodem, 200609-18; 2006. http://www.drenthe.nl/actueel/pers.php?subaction= showfull\&id $=1158580225 \&$ archive $=\&$ start_from $=\& u c a t=3 \&$. (Dutch).

SEQ, ONS, Energy Valley. Noord-Nederland krijgt unieke, schone elektriciteitscentrale: Zero Emission Power Plant. Groningen: ONS Energie NV, SEQ Nederland BV and Stichting Energy Valley; 2005 (Dutch)

Staatsblad. Besluit van 16 augustus 2006 tot wijziging van het Besluit milieu-effectrapportage 1994 (uitvoering richtlijnen nrs. 2001/42/ EG en 2003/35/EG), Staatsblad van het Koninkrijk der Nederlanden (Bulletin of Acts and Orders) nr. 388; 2006 (Dutch).

The Coordinator-General. ZeroGen Clean Coal Power Demonstration Project-draft terms of reference for an EIS; 2006.

TNO. Verkenning naar de mogelijkheden voor de opslag van $\mathrm{CO}_{2}$ en het gebruik van aardwarmte in de provincie Drenthe, opdracht van Province of Drenthe; 2005 (Dutch).

Turner R, Hardy N, Hooper B. Quantifying the risks to the public associated with a $\mathrm{CO}_{2}$ sequestration pipeline: a methodology \& case study. abstract. Proc. of Greenhouse Gas Control Technologies, vol. 8. Trondheim: Elsevier; 2006.

US DOE. Notice of Cancellation of Programmatic Environmental Impact Statement for Implementation of the Carbon Sequestration Program, US Department of Energy - NEPA- Notices. 72. February 26, 2007; 2007.

Van Bergen F, Pagnier HJM, Damen KJ, Faaij APC, Ribberink JS. Feasibility study on $\mathrm{CO}_{2}$ sequestration and enhanced $\mathrm{CBM}$ production in Zuid-Limburg, vol. 76. Novem; 2003.

Vattenfall. Bridging to the future vol. 13; 2005.

Vendrig M, Spouge J, Bird A, Daycock J, Johnsen O. Risk analysis of the geological sequestration of Carbon dioxide. DNV consulting, Department of Trade and Industry, London, UK ; 2003.

Verschuuren J. Restructuring environmental legislation in the Netherlands. Elni Newsl 2004(2).

VROM. Nationaal Milieubeleidsplan 4 - Een wereld en een wil werken aan duurzaamheid. Den Haag, Ministerie van Volkshuisvesting, Ruimtelijke Ordening en Milieubeheer. Juni; 2001.(Dutch).

VROM. Beleidsbrief Ruimtelijke ordening ondergrond. Den Haag; 2004a (Dutch).

VROM. Het Landelijk afvalbeheerplan 2002-2012 (LAP) Deel I Gewijzigde versie van april 2004; 2004 b (Dutch).

VROM. Het Landelijk afvalbeheerplan 2002-2012 (LAP) Deel II en III — Gewijzigde versie van april 2004; 2004c (Dutch).

VROM. Strategische Milieubeoordeling- Aandachtspunten inzake de toepassing van de Europese Richtlijn 2001/42/BG voor Strategische Milieubeoordeling; 2004d (Dutch). 
VROM. Kamerbrief: Toekomstig stelsel van milieueffectbeoordeling, P.L.B.A. van Geel (De Staatssecretaris van Volkshuisvesting Ruimtelijke Ordening en Milieubeheer); 2005a (Dutch).

VROM. Ontwerpbesluit tot wijziging Besluit milieu-effectrapportage 1994 (uitvoering EU-richtlijnen 2001/42/EG en 2003/35/EG), Staatscourant 17 januari 2005; 2005b. nr. 11 / p. 17. (Dutch).

VROM. Toekomstige stelsel van milieubeoordeling - Kamerbrief DGM/SB/BM2004129197; 2005c (Dutch).

VROM. Nota van aanpassing-3e wijziging van het Landelijk afvalbeheerplan 2002-2012. Den Haag, Directoraat-Generaal Milieu, Directie Stoffen, Afvalstoffen, Straling - Algemeen Afvalstoffen Beleid; 2006. (Dutch).

VROM, LNV. Besluit milieu-effectrapportage 1994, as applicable on April 1st 2007; 1994 (Dutch).

Wet milieubeheer; 1979.

Wilson M, Monea M, editors. IEA GHG Weyburn $\mathrm{CO}_{2}$ monitoring \& storage project - summary report 2000-2004. Regina, Canada: Petroleum Technology Research Centre; 2004.

Wood C. Environmental Impact Assessment - a comparitive review. Harlow: Pearson Education; 2003.

Joris M. Koornneef is a Ph.D. student, working at the department of Science, Technology and Society, which is part of the Copernicus Institute for Sustainable Development and Innovation. This multidisciplinary research institute is part of Utrecht University located in the Netherlands. His Ph.D. project aims to find answers on how the impact of the introduction of CCS systems with respect to costs, macro-economy, environment, reliability, industrial development and safety in the Netherlands can be assessed and optimized. The Ph.D. project is part of the Dutch CATO $\left(\mathrm{CO}_{2}\right.$ Capture, Transport and Storage) research program. The aim of CATO is to identify whether and how Carbon Capture and Storage (CCS) can contribute to a sustainable energy system in the Netherlands.
Dr. André P.C. Faaij is an associate professor at the Copernicus Institute - Utrecht University. He has a background in chemistry and environmental sciences and holds a Ph.D. on energy production from biomass and wastes. He worked as a visiting researcher at the Center for Energy and Environmental Studies - Princeton University and at King's College — London University. He coordinates a research cluster on energy supply and system studies $(\sim 25$ research staff involved), covering bio-energy, sustainable use of fossil fuels, intermittent energy sources and energy system studies and modelling. $\mathrm{He}$ is a member of a variety of expert groups in bio-energy and energy policy, research and strategic planning. He works as an advisor for governments, the EC, IEA, FAO, the UN, GEF, OECD, WEF, the energy sector and industry, strategic consultancy, NGO's, etc.

Prof. Dr. Wim C. Turkenburg (1947), trained as physicist, is professor and head of the Department on Science, Technology and Society (STS) of Utrecht University, the Netherlands. Also, he is director of the Copernicus Institute for Sustainable Development and Innovation of Utrecht University. Between 1988 and 2001 he was a working group member of the Netherlands Commission for Environmental Impact Assessment. He also was chairman of the Sub-Committee on Energy of the UN Committee on Energy and Natural Resources for Development (UN-CENRD) and Convening Lead Author of the chapter on Renewable Energy Technologies of the World Energy Assessment (WEA), published in 2000. Currently, he is the vice-chairman of the steering committee of the Dutch CATO $\left(\mathrm{CO}_{2}\right.$ capture, transport and storage) research programme. 